\title{
Devlet Ortaokulu ve Liselerinde Yaşanan Disiplin Problemleri*
}

\section{Discipline Problems at Public Lower Secondary Schools and High Schools}

\author{
Hasan DEMIRTAŞ**, Fatih PEHLIVAN ***
}

\begin{abstract}
Öz: Bu araştırmanın amacı; ortaokul ve liselerde yaşanan disiplin problemlerini, bu disiplin problemlerinin nedenlerine ilişkin öğretmen ve öğrenci görüşlerini ortaya koymaktır. Araştırmada betimsel yöntem kullanılmıştır. Araştırmanın verileri öğretmen ve öğrencilere uygulanan anket ve ölçeklerle elde edilmiştir. Araştırmanın verilerinin analizinde betimsel istatistik analizleri, Mann Whitney U ve Kruskall Wallis testleri, bağımsız gruplar t-testi, tek yönlü varyans analizi yapılmış, eta- kare $\left(\eta^{2}\right)$ ve Cohen's d katsayıları hesaplanmıştır. Araştırma sonuçlarına göre; sınıfın huzurunu bozma, kavga, sigara içme, okul malına zarar verme ve öğrencileri tehdit etme okullarda en yoğun şekilde yaşanan disiplin problemleridir. Mesleki ve Teknik Liselerde araştırmada belirtilen bütün disiplin problemlerinin yaşanma sıklığının diğer lise türlerine göre daha yaygın olduğu belirlenmiştir. Disiplin problemlerinin nedenleri konusunda araştırmaya katılan öğretmen ve öğrenci görüşlerinin ölçeğin bütün boyutlarında anlamlı bir şekilde farklılaştığı ve ölçeğin bütün boyutlarında öğretmenlerin daha yüksek aritmetik ortalamalara sahip oldukları görülmektedir.
\end{abstract}

Anahtar Kelimeler: Okul disiplini, disiplin sorunları, disiplin sorunlarının nedenleri

\begin{abstract}
The aim of this study is to reveal teachers' and students' views regarding the discipline problems and the reasons of these problems at lower secondary schools and high schools. In the study, descriptive method was used. The data in the study was collected through surveys and scales from teachers and students. The data was analyzed by using descriptive statistical analyses, Mann Whitney U and Kruskall Wallis Tests, independent samples t-test, one-way ANOVA, and the eta- square $\left(\eta^{2}\right)$ and Cohen's d coefficient were calculated. According to the results of the study: disruptive behaviors in class, fighting, smoking, damaging school properties and threatening students are the most common discipline problems at schools. Compared to the other schools, it was found out that all discipline problems mentioned in the study have the most frequency of occurrence in Vocational and Technical High Schools. The views of teachers and students regarding the reasons of discipline problems differ significantly in all subscales and for all subscales teachers have higher means.
\end{abstract}

Keywords: School discipline, discipline problems, reasons of discipline problems

\section{Giriş}

Ürünü insan olan eğitim sistemlerinin amacı okullar yoluyla toplumu oluşturan bireylerin yetiştirilmesi ve bir arada yaşamanın gerektirdiği birtakım davranışları kazanmasını sağlamaktır. Günümüz eğitim paradigmasında bireylerin ve toplumun çeşitli sosyal, ekonomik, politik, kültürel ve teknolojik ihtiyaçlarını karşılamak amacıyla okullarda verilen eğitim ile insanların kurallara ve düzenlemelere uymasının sağlanması amaçlanmaktadır (Şimşek, 1997).

Eğitime ilişkin bütün teoriler, düzenli bir öğrenme ortamı yaratarak öğrencilerin okuldaki başarılarını arttırmayı amaçlamaktadır (Tosun, 2002). Öyle ki, okullarda istenilen düzeyde öğrenmenin gerçekleşmesi ve eğitimsel hedeflere ulaşılması öğrencilerin ve okul personelinin kendilerini güvende ve özgür hissettikleri bir eğitim ortamının sağlanmasına bağlıdır (Güven ve Dönmez, 2002). Okullarda verimli ve etkin bir eğitim ve öğretimin gerçekleştirilmesinin ön koşulu güvenli, düzenli ve disiplinli bir okul ve sınıf ortamının oluşturulmasıdır (Özdemir, 2007).

\footnotetext{
* Bu çalışma, ikinci yazarın, birinci yazar danışmanlığında, İnönü Üniversitesi Eğitim Bilimleri Enstitüsü’nde yürütülen “Ortaokul ve Liselerde Yaşanan Disiplin Problemlerinin Bazı Değişkenler Açıcından İncelenmesi” başlıklı doktora tezinden üretilmiştir

** Doç. Dr., İnönü Üniversitesi, Eğitim Fakültesi, Malatya-Türkiye, ORCID:0000-0002-4223-5786, e-posta: hasan.demirtas@inonu.edu.tr

*** Dr., MEB, Malatya, Türkiye, ORCID: 0000-0003-3258-6635 e-posta: fatihpehlivan@ yahoo.com
} 
Okullarda uygulanan disiplinin amacı; öğrenciye kendi davranıșını istenen davranıșlarla kıyaslayarak öz denetleme, öz değerlendirme alışkanlığı ve yeterliği kazandırmak, öğrencinin sosyalleşmesini geliştirmek; doğru düşünme ve değerlendirme ölçütü çerçevesinde hareket etme alışkanlığı vermek (Sarıtaş, 2003), okulda uyulması gereken davranışların ilke ve kurallarını öğretmek, öğrencilerin bu ilke ve kurallara uygun olarak davranıp davranmadığını izlemektir (Başaran, 2000).

Okulda disiplini sağlamak öğrencilere öğrenme ortamı oluşturmak için bir araçtır. Öyle ki, öğrenciler düzensiz ve güvenli olmayan bir sınıfta ya da okulda öğrenemezler. Her ne kadar iyi disiplin etkili öğrenmeyi garanti etmese de, iyi bir okul disiplini öğrencilerin önceki öğrenmeleri, mevcut kaynaklar, öğrencilerin motivasyonu gibi öğrenmeyi etkileyen önemli bir etkendir. Öğrencilerin sosyalleşmesinde okul önemli ve kaçınılmaz bir rol oynar (Munn ve diğerleri, 2000).

İyi yapılandırılmış bir disiplin sistemindeki yaptırımlar ve düzenlemeler, öğrencilerin istenmeyen davranıșlar sergilememesi için caydırıcı nitelik taşıyabilir. Her ülkenin eğitim sisteminin genel amacı, uygun davranışlarla donatılmış bireyler yetiştirmektir. Bununla birlikte ileri demokratik ülkelerde özgürlük bir sorun haline gelmekte; temel özgürlükler yayılıp yaygınlaştıkça okul eğitimi, okul çağındaki çocuklara sınırlayıcı ve zorlayıcı bir baskı aracı gibi görünmeye başlamaktadır (Güvenç ve diğerleri, 1990). Disiplin problemlerinin daha sık görüldügü okullarda öğretmenlerin öğretim sürecini başlatabilmesi için düzenli bir ortam oluşturması ve bunun için de daha fazla zaman harcaması gerekmektedir. 2009 yılında yayımlanan Uluslararası Öğrenci Değerlendirme Programı (PISA) sonuçları okulda oluşturulan disiplin ikliminin öğrenci performansı ile yüksek düzeyde ilişkili olduğunu göstermektedir (OECD, 2011).

Okullarda eğitsel çabaları engelleyen her türlü davranış istenmeyen davranış olarak nitelendirilmektedir (Başar, 1999). Okul disiplini ile ilgili yapılan araştırmalarda (Gupta, 2006; Güven ve Dönmez, 2002; Marzano, 2003; Marzano, Marzano ve Pickering, 2008; Sarpkaya, 2007; Siyez, 2009; Şişman ve Turan, 2008) okul genelinde istenmeyen öğrenci davranışları; öğrenci kavgaları, kural ve yönetmeliklere itaatsizlik, öğretmenlere saygısızlık, sınıfa geç gelme, okuldan kaçma, zorbalık, argo sözcükler ve hakaretler, öğrenci-öğretmen anlaşmazlıkları, okul çevresindeki bazı kişilerin öğrencileri rahatsız etmeleri okullarda disiplin bozucu davranışları olan öğrencilerin olması, bazı öğrencilerin başka öğrenciler tarafından zorla paralarının ya da eşyalarının alınması, hırsızlık, okulda kanunen yasaklanmış suç aleti bulundurma, öğretmenleri tehdit eden öğrenciler, çeteleşme, cinsel taciz, dersin işlenmesinin sürekli olarak engellenmesi, gürültü yapma ve sınavlarda kopya çekme, kılık kıyafetine özen göstermemek, derslere ilgisizlik, derste konuşma, dersle ilgili sorumluluk almak istememe, derste söz almadan konuşma, kopya çekme davranışları olarak sıralanmaktadır.

\section{İstenmeyen öğrenci davranışlarının nedenleri}

Okul ortamında istenilen düzeyde bir disiplinin varlığını sağlamak için garantili bir yol yoktur. Fakat pozitif bir eğitim ortamı oluşturmak, etkili ve başarılı bir okul ortamı yaratmak için (Ada ve Çetin, 2006) öğrenci, aile, yöneticiler, okulun fiziksel yapısı gibi birtakım etkenlerin göz önünde bulundurulması gerekir.

Öğrenciler arasında sosyal, ekonomik ve psikolojik yönlerden çok çeşitli farklılıklar vardır. Ailenin gelir ve eğitim düzeyi, çocuk sayısı, değerleri, inançları, ana babanın mesleği, çocuğa ve okula karşı tutumları, eğitime verdikleri değer, çocuğun cinsiyeti, yetenekleri, fiziksel özellikleri, yaşı gibi birçok yönden öğrenciler birbirlerinden farklıdırlar. Bütün bu farklı özellikleriyle sınıfa gelen öğrencilerin davranışlarında, olaylara bakış açılarında, kendilerini ifade etmede farklılıkların olması doğaldır (Şişman ve Turan, 2008).

Sınıf düzeninde ve öğrenmenin etkililiği konusunda sınıf içi ilişkiler dokusu önemli bir yer tutmaktadır. Öğretmen, gücü ve öğretimin amaca ulaşması açısından bu yapıyı sağlıklı bir şekilde oluşturmalıdır (Celep, 2000). Öğretmenin sınıf yönetimi konusundaki yeterliliği öğrenci davranışlarını yönetmede ve disiplini sağlamada kolaylık sağlayacaktır (Şişman ve Turan, 2008). 
Eğitsel liderler olarak okul yöneticileri okulun kültür, değer ve inançları ile uyumlu, okul çapında disiplini sağlayacak bir öğrenme ortamı oluşturmak için gayret göstermelidir. Kurumsal disiplini etkileyen faktörler; öğrenci performans, tutum ve davranışının yönetimi ve alınan önlemlerdir. Bu önlemler şu konuları içermektedir (Deshmukh ve Naik, 2010): akademik başarım, okula ve özellikle öğretilen derslere yönelik tutumlar, sosyal davranış problemleri (disiplin problemleri, zorbalık, alkol vb.), ait olma/yabancılaşma duygusu,okulu bırakma oranları vb., öğretmenlerin tutum ve işbirliği, öğretim programının niteliği.

Davranış oluşturma ve değiştirme amaçlı etkinlikler bütünü olarak nitelendirilen eğitim süreci okullar yoluyla yürütülmektedir. Okullar öğrencileri dış çevrenin güçlüklerinden korumak ve onlar için yaşamı kolaylaştırmak, dış çevrede kolay rastlanabilecek istenmeyen nitelikteki davranışları okulun içine sokmayarak öğrenci davranışlarını düzenlemek ve toplumsal yaşamda olmayan dengeyi aynı forma, sıra, öğretmen vb. unsurlar ile kendi sınırları içerisinde kurması gereken kurumlardır (Başar, 1999).

Okul çapında disiplin politikası, her öğretmenin sınıf içi davranış standartları geliştirmesi açısından genel ilkeleri oluşturabilir. İdeal olarak, bu ilkeler bir öğretmenin standartlarının diğer öğretmenlerinkiyle çatışmasını önlemek için yeterli yönlendirme sağlarken öğretmenlere bir otonomi verecek esnekliktedir. Okul çapındaki disiplin politikası bireysel olarak öğretmenin sınıf standartlarının uygulanmasını destekleyici olabilir (Cangelosi, 2016).

Disiplin ve öğretim programı birbirinin ayrılmaz bir parçası olarak kabul edilmektedir. Birbirinden net bir şekilde bağımsız gibi görünseler de, amaçlar ve süreçlerde bu ikisinin bir bütün olduğu ve birbirini tamamladığı görülmektedir. Olası disiplin problemleri bütünleşik öğretimsel süreçlerin uygulanmasıyla önlenebilir. Yani herhangi bir disiplin problemi öğretmen tarafından öğretimsel içeriğge dahil edilebilir (Edwards, 2011).

Sınıfın fiziksel yapısının düzeni öğretmenin öğretim etkinliklerini rahat bir biçimde yürütmesinde ve öğrencinin derse etkin katılımında önemli rol oynamaktadır (Celep, 2000). Sınıf ortamının fiziksel düzenine ilişkin etkinlikler, sınıf yönetimi etkinliklerinin diğer bir boyutudur. Sınıf ortamının genişliği, sınıf alanının çeşitli etkinliklerin yapımı için bölünmesi, 1s1, 1şık, gürültü düzenekleri, renkler, temizlik, estetik, eğitsel araçlar, oturma düzeni öğrencilerin gruplanması bunların başlıcalarıdır (Ada ve Çetin, 2006; Başar, 2014).

Okullarda yaşanan disiplin problemlerine neden olan etmenler sadece okul içindeki durumlarla da sınırlı değildir. Öğrencilerdeki istenmeyen davranışlarının okul dışı birçok durumdan da etkilenebileceği söylenebilir. Öyle ki, insan davranışları onun parçası olduğu doğanın, çevrenin bilinmesi halinde daha iyi anlaşılır (Türnüklü, 2006). Öğrencinin yaşadığı ve okulun bulunduğu çevre, aile ile ilgili konular vb. unsurlar bu davranışların tetikleyicisi olabilir. Okulda karşılaşılan disiplin sorunlarının çoğunun temelinde çocuğun ailede kazanmış olduğu kişilik özellikleri ve alışkanlıklar yatmaktadır (Ada ve Çetin, 2006).

Okullarda yaşanan disiplin problemleri, okullarda gittikçe büyüyen bir sorun olarak karşımıza çıkmaktadır. Okullarda karşılaşılan istenmeyen davranışların niteliği, türü, şiddeti ve bunların nedenleri okuldan okula farklılık göstermektedir. Bu çalışmanın amacı okullarda yaşanan disiplin problemleri ve bunların nedenlerini öğretmen ve öğrenci görüşlerine dayalı olarak ortaya koymaktır.

$\mathrm{Bu}$ amaç doğrultusunda araştırmada aşağıdaki sorulara yanıt aranmıştır:

- Milli Eğitim Müdürlüğü verileri ile öğretmen ve öğrenci görüşlerine göre okullarda yaşanan disiplin problemleri nelerdir ve bu disiplin problemlerinin yaşanma sıklığı, öğretmen ve öğrenci görüşlerine göre eğitim kademesine (ortaokul, lise), liselerde ise lise türüne göre (Anadolu Lisesi, Fen Lisesi ve Mesleki ve Teknik Lise) göre anlamlı farklılık göstermekte midir?

- Öğretmen ve öğrencilerin disiplin problemlerinin nedenlerine ilişkin görüşlerinin dağılımı nasıldır ve bu dağılım öğretmen ve öğrenci görüşlerine, öğretmenlerin cinsiyeti ve meslekteki kıdemlerine göre ve öğrencilerin cinsiyet ve eğitim kademesine göre anlamlı bir şekilde farklılaşmakta mıdır? 


\section{Yöntem}

$\mathrm{Bu}$ araştırma, tarama modeline dayalı betimsel bir çalışmadır. Araştırmada öğretmenlerin ve öğrencilerin disiplin problemlerine ve nedenlerine ilişkin görüşlerinin cinsiyet, kıdem, okul türü, okulların bulunduğu çevrenin sosyo-ekonomik düzeyi değişkenlerine göre anlamlı farklılık gösterip göstermediğinin belirlenmesinde bireyler ya da gruplar arasındaki farklılıkların nedenleri ve sonuçlarını belirlemede başvurulan nedensel karşılaştırmalı desen (Fraenkel, Wallen ve Hyun, 2012) kullanılmıştır.

\section{Evren ve örneklem}

Araştırmanın evrenini 2016-2017 öğretim yılında Malatya merkez ilçelerde bulunan resmi ortaokul ve liselerdeki öğretmenler $(\mathrm{N}=6141)$ ve öğrenciler $(\mathrm{N}=68921)$ oluşturmaktadır. Araştırmada belirli bir değişken dikkate alınarak, değişkene ilişkin evrenin sahip olduğu özelliklerin örneklemde de aynı oranda temsil edilmesinin amaçlandığı tabakalı örnekleme yöntemine başvurulmuştur (Altunışık ve diğ., 2010). Araştırma kapsamında öğretmen ve öğrencilerin evren ve örnekleme dağılımı Tablo-1'de verilmiştir. Okullarda uygulanan anketlerden içtenlikle, tam ve eksiksiz olarak yanıtlandığ öğretmen ve 1001 öğrenci anketi analizler için değerlendirmeye alınmıştır.

Tablo 1.

Öğrenci ve Öğretmen Sayılarının Evren (N) ve Örnekleme (n) Dağılımı

\begin{tabular}{cccccccccc}
\hline Değişken & & \multicolumn{4}{c}{ Öğretmen } & \multicolumn{5}{c}{ Öğrenci } \\
& & $\mathrm{N}=6141$ & $\%$ & $\mathrm{n}=691$ & $\%$ & $\mathrm{~N}=68921$ & $\%$ & $\mathrm{n}=1.001$ & $\%$ \\
\hline Cinsiyet & Kadın & 2.559 & 41,6 & 349 & 50,5 & 32.750 & 47,5 & 504 & 50,3 \\
$\begin{array}{c}\text { (Ortaokul- } \\
\text { Lise) }\end{array}$ & Erkek & 3.582 & 58,4 & 342 & 49,5 & 36.114 & 52,5 & 497 & 49,7 \\
\hline Okul türü & Ortaokul & 3.160 & 51,5 & 414 & 59,9 & 34.887 & 50,6 & 449 & 44,9 \\
$\begin{array}{c}\text { (Ortaokul- } \\
\text { Lise) }\end{array}$ & Anadolu L. & 1.088 & 36,5 & 113 & 16,4 & 14.142 & 41,5 & 257 & 25,7 \\
& Fen/ Sosyal & 121 & 4,1 & 35 & 5,1 & 1.540 & 4,5 & 109 & 10,9 \\
& B. L. & & & & & & & & \\
& $\begin{array}{c}\text { Mesleki ve } \\
\text { Teknik L. }\end{array}$ & 1.772 & 59,4 & 129 & 18,7 & 18.352 & 54 & 186 & 18,6 \\
\hline
\end{tabular}

\section{Veri toplama araçlari}

Okullarda yaşanan disiplin problemlerinin ve bu problemlerin nedenlerinin belirlenmesinde araştırmacı tarafından geliştirilen "Okullarda Yaşanan Disiplin Problemleri Anketi" ve "Okullarda Yaşanan Disiplin Problemlerinin Nedenleri Ölçeği” kullanılmıştır.

Veri toplama araçlarının geliştirilmesi sürecinde belirlenen ortaokul ve liselerdeki öğretmen ve öğrencilere dağıtılan formlar aracılığıyla görüşleri sorulmuştur. Araştırmaya gönüllü olarak katılan farklı okul türlerinden 145 öğretmen ve 446 öğrenciden toplanan bu formlardaki veriler değerlendirilerek disiplin problemleri ve nedenleri belirlenmiştir. Oluşturulan ölçme araçlarının kapsam geçerliliğini sağlamak amacıyla alınan uzman görüşlerinin değerlendirilmesinden sonra veri toplama aracında yer alan maddeler okullarda yaşanan disiplin problemleri için 28 madde, bu problemlerin nedenleri için ise 48 madde olarak düzenlenmiştir.

Anketin geliştirilmesi sürecinde öncelikle konuyla ilgili yapılan alan yazın taraması sonucu disiplin problemlerine ilişkin alt alanlar belirlenmiş, araştırmada vurgulanan demografik değişkenlere dayalı olarak belirlenen ortaokul ve liselerdeki öğretmen ve ögrencilere dağıtılan formlar aracılığıyla "Okulunuzda yaşanan disiplin problemleri nelerdir?" ş̧eklinde açı uçlu olarak sorulmuş soruya katılımcıların yanıt vermesi beklenmiştir. Araştırmaya konu olan disiplin problemleri ile ilgili elde edilen bulgulardan yararlanılarak bir madde havuzu oluşturulmuş, araştırma sorularının belirlenmesi için yapılan ön-uygulamada öğretmen ve öğrenci görüşlerine dayalı olarak okullarda yaşanan disiplin problemlerinin neler olduğunun sayısal dökümü yapılmıştır. Öğretmen ve öğrenci görüşlerine dayalı olarak oluşturulan bu soruları desteklemek için disiplin yönetmelikleri incelenerek, öğrenciler ve öğretmenler tarafından vurgulanmayan 
noktalar ankete eklenmiş ve okullarda yaşanan disiplin sorunlarıyla ilgili 33 maddelik denemelik veri toplama aracı oluşturulmuştur. Oluşturulan veri aracının kapsam geçerliliğini sağlamak amacıyla, İnönü Üniversitesi'nden Eğitim Yönetimi alanında üç öğretim üyesi, Psikolojik Danışma ve Rehberlik alanında bir öğretim üyesi, Eğitim Programları alanında bir öğretim üyesi, Osmangazi Üniversitesi Eğitim Yönetimi ve Denetimi Bölümünden bir öğretim üyesi, Pamukkale üniversitesi Eğitim Yönetimi ve Denetimi bölümünden bir öğretim üyesi ve biri ortaokul biri de lise olmak üzere iki rehber öğretmenin görüşlerine başvurulmuştur. Uzman görüşlerinin değerlendirilmesinden sonra veri toplama aracında yer alan maddeler okullarda yaşanan disiplin problemleri için 28 madde olarak düzenlenmiş ve "Okullarda Yaşanan Disiplin Problemleri Anketi" olarak kullanılmasına karar verilmiştir. Bu anket beşli likert tipi sorular olarak hazırlanmıştır. Likert-tipi sorular kullanılarak oluşturulan anketler likert ölçeği ile aynı özellik göstermemektedir. Likert ölçekleri katılımcının bir konu hakkındaki genel görüşüne ulaşmak için tek tek sorulara verdiği cevapların toplamının alındığı ölçeklerdir. Likert-tipi sorular 1'den başlayarak soruda kullanılan seçenek sayısınca kodlanır. Bu kodlamada en olumsuz cevap en düşük bir (1) rakamı ile en olumlu cevap ise en yüksek rakam beş (5) ile temsil edilir. Bu sıralı kodlamadan dolayı Likert tipi sorular siralı (ordinal) veri olarak kabul edilir. Sorulan sorularda Likert tipi beşli derecelendirme kullanılmıştır. Bunlar 1-Hiçbir zaman, 2-Nadiren, 3-Bazen, 4-Slk sik ve 5-Her zaman şeklindedir.

Araştırmada okullarda yaşanan disiplin problemlerinin nedenlerini belirlemek amacıyla 48 maddelik veri toplama aracının ölçek olarak düzenlenmesi planlanmıştır. Denemelik ölçeğin yapı geçerliliğinin test edilmesi amacıyla açımlayıcı faktör analizi (AFA) ve doğrulayıcı faktör analizi (DFA) teknikleri kullanılmıştır. AFA ve DFA çalışmaları için iki ayrı örneklem üzerinde pilot uygulama yapılmıştır. Denemelik ölçek formu 2016-2017 eğitim öğretim y1lı ikinci yarıyılında Malatya ili merkez ilçe sınırları içerisinde bulunan 12 okulda görev yapan 221 öğretmene uygulanmıştır. AFA öncesinde, verilerin faktör analizine uygunluğu Kaiser-MayerOlkin (KMO) katsayısı ve Bartlett's Test of Sphericity testiyle incelenmiştir. KMO katsayısının 0.60 'dan yüksek olması durumunda, verilerin faktör analizi için uygun olduğunu kabul edilmektedir (Büyüköztürk, 2014). Elde edilen değerlere göre (Kaiser Meyer Olkin = .950, Bartlett's Test of Sphericity $=13795,17, \mathrm{df}=406, \mathrm{p}=.000$ ), verilerin faktör analizi için uygun olduğu sonucuna ulaşıldıktan sonra açımlayıcı faktör analizine geçilmiştir. Açımlayıcı faktör analizinde, yaygın kullanılan tekniklerden biri olan ve değişken azaltma ve anlamlı kavramsal yapılara ulaşmayı amaçlayan temel bileşenler analizi kullanılmıştır (Büyüköztürk, 2014). Analizden elde edilen faktörlerin yorumlanması ve isimlendirilmesini kolaylaştırmak için yaygın bir dik döndürme tekniği olan Varimaxtan yararlanılmıştır (Altunışık ve diğerleri, 2010).

Faktörlerin oluşturulmasında faktör yük değerlerinin .30 ya da daha yüksek olması, maddelerin tek bir faktörde yüksek yük değerine diğer faktörlerde ise, düşük yük değerine sahip olması ve birden fazla faktörde yüksek yük değeri almaları, durumunda ise her iki yük değeri arasındaki farkın en az .10 olması, her bir faktörün özdeğerinin en az 1 olması ölçütleri dikkate alınmıştır (Büyüköztürk, 2014).

Yapılan ilk açımlayıcı faktör analizi sonucunda, belirtilen ölçütlere uymayan toplam 19 madde ölçekten çıkarılarak faktör analizi yinelenmiştir. Yinelenen AFA sonuçları Tablo-2'de gösterilmiştir.

Tablodaki bulgular incelendiğinde, önemli olarak belirlenen faktörlerden birincisinin ölçeğe ilişkin toplam varyansın \%40,67'sini, ikincisinin \%8.4'ünü, üçüncüsünün \% 6,87, dördüncüsünün \%4.68'ini, beşincisinin \%4,33'ünü ve altıncısının ise \%3.7'sini açıkladığı görülmektedir. Altı faktör tarafindan açıklanan toplam varyans oranı ise \%68,74'tür. Büyüköztürk (2014) analiz edilen değişkenlerle ilgili toplam varyansın 2/3'ü kadar miktarının ilk olarak kapsadığı faktör sayısının önemli faktör sayısı olarak değerlendirilebileceğini ifade etmektedir. Bu araştırmadaki ölçme aracında altı faktör tarafından açıklanan varyansın yeterli olduğu sonucuna ulaşılmıştır.

Yapılan AFA sonucunda ölçeğin toplam 29 maddeden oluşan altı faktörlü bir yapıya sahip olduğu görülmüştür. Faktör analizi sonucu elde edilen her bir faktör isimlendirilirken, faktörlerde yer alan maddelerin içerikleri göz önünde bulundurulmuştur. 
Ölçek maddelerinin güvenilirliğine ilişkin bulgular incelendiğinde, ölçekten elde edilen verilerin güvenirliğine ilişkin Cronbach Alfa iç tutarlılık katsayılarının birinci faktör için .938, ikinci faktör için .881, üçüncü faktör için .833 , dördüncü faktör için .854 beşinci faktör için .828 ve altıncı faktör için ise .803 ve ölçek maddelerinin toplamı için ise .947 olarak hesaplanmıştır. görülmüştür. Kline (2011) genel olarak güvenirlik katsayısının .90 civarında mükemmel, .80 civarında çok iyi, olduğunu belirtmektedir. Buna göre ölçek için hesaplanan Cronbach Alfa iç tutarlılık katsayılarının birinci ve ikinci faktörler için mükemmel diğer faktörler için çok iyi değerler verdiği görülmüştür.

Tablo 2.

Okullarda Yaşanan Disiplin Sorunlarının Nedenleri Ölçeğinin AFA Sonuçları

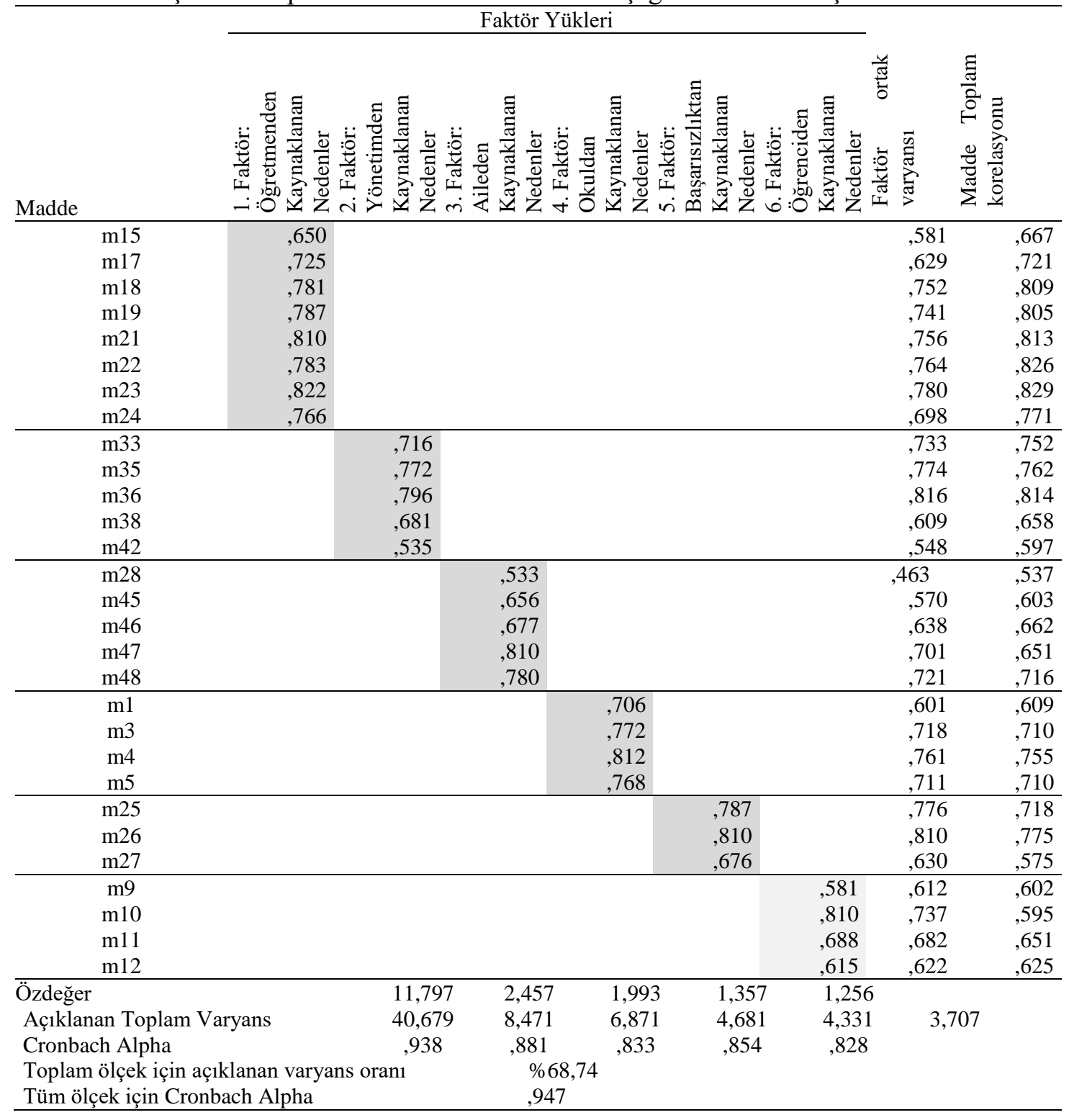

Açımlayıcı faktör analizinde elde edilen altı faktörlü yapıyı test etmek amacıyla Doğrulayıcı Faktör Analizi (DFA) yapılmıştır. Bu amaçla 15 okulda görev yapan 274 öğretmene "Okullarda Yaşanan Disiplin Problemlerinin Nedenleri” ölçeği uygulanmıştır. İkinci pilot uygulama sonucu elde edilen ölçek formları arasından eksik/hatalı doldurulanlar ve ardından uç değerlere sahip formlar çıkarılmıştır. Bu işlemler tamamlandıktan sonra geriye kalan 241 
öğretmenden elde edilen veriler üzerinden yapılan DFA sonucunda altı boyutlu yapıya ilişkin uyum iyiliği indeksleri bulunmuştur.

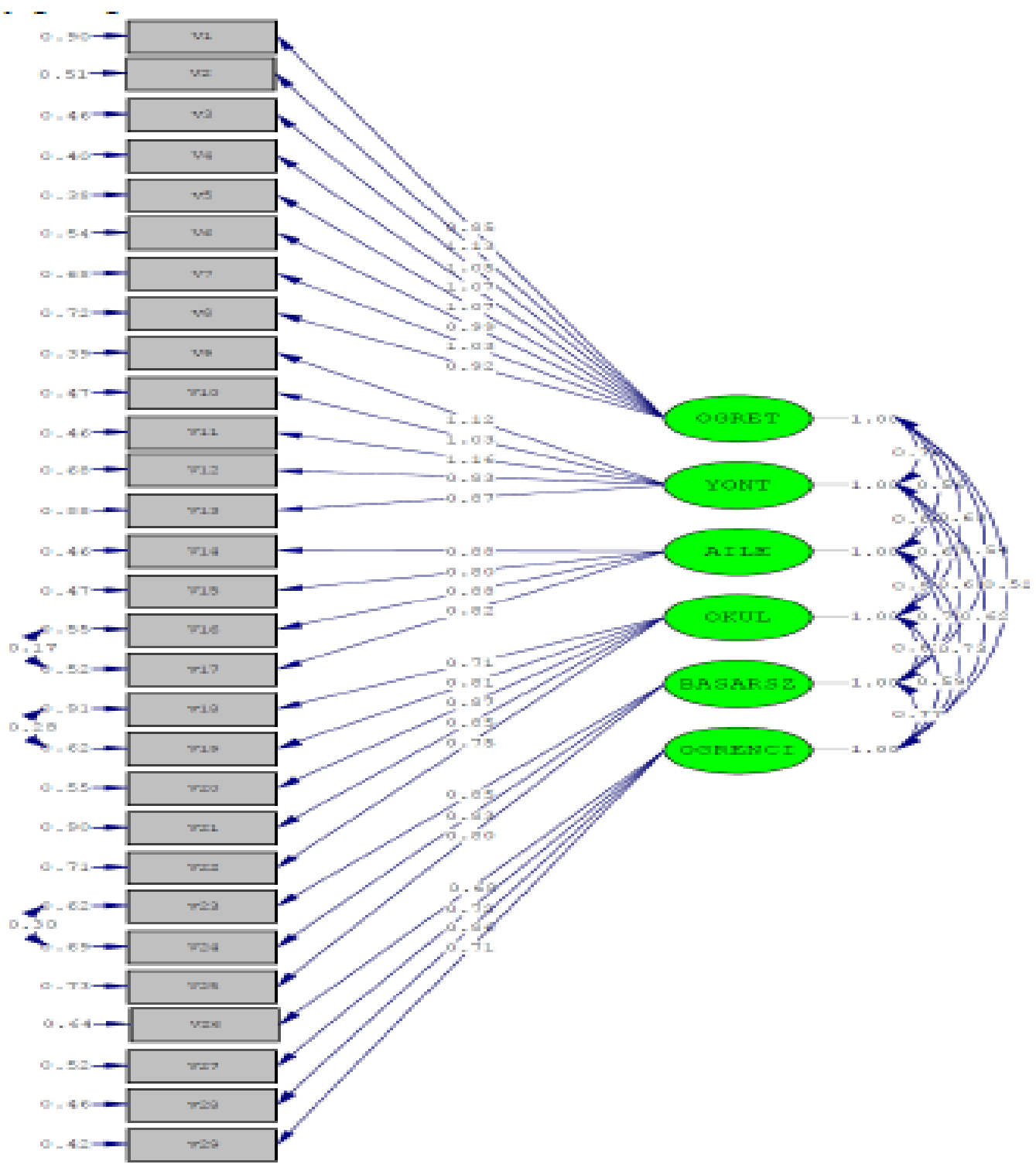

Şekil 1. Ölçeğin alt boyutlarına ilişkin standardiz edilmiş çözümleme değerlerinin diyagram gösterimi

Alanyazında $\chi 2$ değerinin serbestlik derecesine bölümü ile elde edilen sonucun $(\chi 2 / \mathrm{sd}) 3$ ya da daha az olması modelin uyumunun iyi olduğunu, 2 ile 5 arasında olması ise model-veri uyumunun kabul edilebilir düzeyde olduğunu gösterir. GFI, AGFI, NNFI ve CFI değerlerinin .90 ya da üzerinde olması kabul edilebilir, .95 ya da daha yüksek olması ise modelin iyi uyuma sahip olduğunu gösterir. RMSEA, RMR ve SRMR göstergelerinde ise, .05 ve altındaki değerler modelveri uyumunun iyi olduğunu, .08'e kadar ise kabul edilebilir olduğunu gösterir (Gürbüz ve Şahin, 2014).

Altı alt boyut ve toplam 29 maddeden oluşan ölçeğin yapılan DFA sonucunda elde edilen uyum iyiliği değerleri incelendiğinde GFI ve AGFI indekslerinin kabul edilebilir sınırların altında kaldığı, diğerlerinin ise kabul edilebilir ya da iyi sınırlar içerisinde olduğu görülmüştür. $\mathrm{Bu}$ yüzden modelin veriye uyumu açısından iyileşme elde etmek amaciyla düzeltme endeksleri kontrol edilmiştir DFA düzeltme endekslerinde 16. ve 17. madde çifti, 18. ve 19. madde çifti ve 
23. ve 24. madde çiftinin hatalarının ilișkili olduğu ve ilișkinin modele eklenmesinin önerildiği görülmüştür. Bu düzeltmeler yapıldıktan sonra model tekrar test edilmiş ve aşağıdaki sonuçlar elde edilmiştir.

Ki-Kare $(\chi 2)=1089.93, S d=359(\chi 2 / S d=3.303)$

Uyum Iyiliği Indeksi (Goodness of Fit Index, GFI) $=0.90$

Düzeltilmiş Uyum Iyiliği İndeksi (Adjusted Goodness of Fit Index, AGFI) $=0.88$

Normlaştırılmamış Uyum Indeksi (Non-Normed Fit Index, NNFI) $=0.98$

Karşılaştırmalı Uyum Indeksi (Comparative Fit Index, CFI) $=0.99$

Yaklaşık Hataların Ortalama Karekökü (Root Mean Square Error of Approximation, RMSEA) = 0.054

Artık Ortalamaların Karekökü (Root Mean Square Residuals, RMR) $=0.057$

Standardize Edilmiş Artık Ortalamaların Karekökü (Standardized RMR) = 0.041

$\mathrm{Bu}$ veriler 1şı̆̆ında bu araştırmada test edilen modelin, AGFI (.88) değeri dişında, tüm uyum iyiliği kriterleri açısından iyi değerlere sahip olduğunu göstermektedir. Elde edilen bu bulgular ölçme modelinin altı faktörlü yapısının doğrulandığı şeklinde yorumlanabilir.

\section{Verilerin analizi ve çözümlenmesi}

Okullarda Yaşanan Disiplin Problemleri Anketi likert tipi sorulardan oluşmaktadır. Likert-tipi sorularla oluşturulan bir ankette, sorular ordinal veri olarak kabul edildiğinden ve her soru ayrı ayrı analiz edildiğinden dolayı elde edilen verilerin istatistiksel analizinde parametrik olmayan istatistiksel testlerin kullanılması gerekmektedir (Turan ve diğerleri, 2015). Araştırmada okullarda yaşanan disiplin problemleri için toplanan verilerin analizinde aritmetik ortalamalar, Mann Whitney U testi ve Kruskall Wallis Testi kullanılmıştır. Mann-Whitney U testi uygulanan değişkenlerden, anlamlı farklılık olan maddeler üzerindeki etki düzeyini hesaplamak için " $r$ etki büyüklügü istatistiğg”" kullanılmıştır. Bir testin anlamlı olması ölçtügü etkinin önemli olduğu anlamına gelmeyebilir. Etki büyüklüğünün hesaplanması standartlaştırılmış bir ölçüm sağlayarak diğer araştırmalarla karşılaştırmaya olanak tanır. Etki büyüklüğü gözlemlenen etkinin büyüklüğünün nesnel ve standartlaştırılmış bir şekilde ölçülmesidir. $r>.5$ değeri büyük etki miktarını, $\mathrm{r}>.3$ orta etki miktarını, $\mathrm{r}>.1$ küçük etki miktarını belirtmektedir (Field, 2005).

Araştırmada öğretmenlerin ve öğrencilerin disiplin problemlerinin nedenleri ile ilgili görüşlerinin analizinde aritmetik ortalama, standart sapma puanları, t-testi ve tek yönlü varyans analizi (One-Way ANOVA) uygulanmıştır. Araştırmada öğretmen ve öğrenci görüşlerinin statü (öğretmen-öğrenci), cinsiyet ve eğitim kademesine göre anlamlı biçimde farklılaşıp farklılaşmadığını belirlemek amacıyla bağımlı değişkene ilişkin ölçümlerin dağılımının her iki grupta da normal olduğu ve karşılaştırılacak iki ilişkisiz örneklemin ortalamaları arasındaki farkın manidar olup olmadığını test etmek için kullanılan t-testi (Büyüköztürk, 2014); öğretmen görüşlerinde kıdem değişkenine bağlı olarak anlamlı bir ilişkininin olup olmadığını belirlemek amacıyla ilişkisiz iki ya da daha çok örneklem ortalaması arasındaki farkın sıfırdan anlamlı bir şekilde farklı olup olmadığını test etmek üzere kullanılan (Büyüköztürk, 2014) tek yönlü varyans analizi (One-Way ANOVA) uygulanmıştır. Çıkarımsal analiz sonuçlarının yorumlanmasında etki büyüklüğü değerleri ( $\eta 2$ ve Cohen d) kullanılmıştır. Grup ortalama puanları arasındaki farkların test edilmesinde $\mathrm{p}<0.05$ anlamlılık düzeyi esas alınmıştır.

\section{Bulgular}

Araştırmanın bu bölümünde, okullarda yaşanan disiplin problemleri ile ilgili olarak elde edilen verilerin analizi sonucunda ulaşılan bulgular araştırmanın alt problemlerine göre sunulmuş ve yorumlanmıştır.

\section{Okullarda yaşanan disiplin problemleri}

2015-2016 Eğitim-Öğretim döneminde Malatya merkez ilçelerde okullarda yaşanan disiplin problemleri ile ilgili olarak okullar tarafindan Rehberlik ve Araştırma Merkezlerine gönderilen Şiddet Olayları Formu incelenmiş ve yaşanan olayların sayısal dökümü yapılmıştır. Okullara 
gönderilen formlardan 52'si ortaokullar ve 38'i de liseler olmak üzere toplamda 90 okuldan elde edilen veriler Tablo 3'te sunulmaktadir.

2015-2016 Eğitim-öğretim dönemine ilişkin verilere bakıldığında toplamda 951 vakanın yaşandığı görülmektedir. Bu vakalardan Sinıfin huzurunu bozma $(f=286)$, Kavga $(f=213)$, Sigara içme $(f=179)$ ve Ögrencileri tehdit etme $(f=67)$ olaylarının yaşanma sıklığının diğer sorunlara göre daha fazla olduğu anlaşılmaktadır. Sinıfin huzurunu bozma $(f=174)$, ögrencileri tehdit etme $(f=42)$ ve okul araç gereçlerine zarar verme $(f=23)$ davranışları ortaokullarda daha yoğun bir şekilde görülürken, kavga $(f=131)$ ve sigara içme davranışları $(f=172)$ ise liselerde daha yaygindır.

Tablo 3.

2015-2016 Okullarda Yaşanan Şiddet Olaylarının Ortaokul ve Liselere Dağılımı

\begin{tabular}{lcccccc}
\multicolumn{1}{c}{\begin{tabular}{c} 
OKULLARDA YAŞANAN ŞİDDET \\
\multicolumn{1}{c}{ OLAYLARI }
\end{tabular}} & \multicolumn{2}{c}{ Ortaokul } & \multicolumn{2}{c}{ Lise } & \multicolumn{2}{c}{ TOPLAM } \\
(f) & $\%$ & (f) & $\%$ & (f) & $\%$ \\
\hline Sinıfın Huzurunu Bozma & 174 & 50 & 112 & 19 & 286 & 30 \\
Kavga & 82 & 22 & 131 & 23 & 213 & 22 \\
Sigara içme & 7 & 1 & 172 & 30 & 179 & 19 \\
Öğrencileri Tehdit Etme & 42 & 11 & 25 & 4 & 67 & 7 \\
Diğer & 3 & 0,1 & 58 & 10 & 61 & 6 \\
Okul Araç Gereçlerine Zarar Verme & 23 & 6 & 16 & 2 & 39 & 4 \\
Bilişim Suçları & 9 & 2 & 20 & 3 & 29 & 4 \\
Öğretmenlere Hakaret- Tehdit Eme & 7 & 2 & 12 & 2 & 19 & 2 \\
Uyuşturucu Madde Kullanımı & 0 & 0 & 17 & 3 & 17 & 2 \\
Okul içinde alkol bulundurulması ve kullanımı & 0 & 0 & 14 & 2 & 14 & 1 \\
Hirsızlik & 9 & 2 & 1 & 0,1 & 10 & 1 \\
Taciz & 8 & 2 & 1 & 0,1 & 9 & 1 \\
Okula kesici delici aletler getirme & 3 & 0,1 & 0 & 0 & 3 & 0,3 \\
Çeteleşme/Gruplaşma & 4 & 1 & 0 & 0 & 4 & 0,4 \\
Gasp & 0 & 0 & 1 & 0,1 & 1 & 0,1 \\
\hline TOPLAM & 371 & 100 & 580 & 100 & 951 & 100 \\
\hline
\end{tabular}

\section{Öğretmen ve öğrenci görüşlerine göre, okullardaki disiplin problemleri}

Okullardaki disiplin problemlerine ilişkin öğretmen görüşlerinin daha çok bazen düzeyinde yoğunlaştığ1 görülmektedir. Tablo 4'te görüldüğü üzere, öğretmen görüşlerine göre anket maddelerinde belirtilen disiplin sorunlarından; M25 Koridor ve merdivenlerde birbirini itme, gürültü ve kargaşa yaşanması $(X=3,12), M 1$ Öğrencilerin giyim tarzlarının kllık-klyafet kurallarına uygun olmaması $(X=3,11)$, M8 Dersin akışını ve sınıf düzenini bozacak tavır ve davranışlar sergileme $(X=3,10)$, M9 Dersle ilgili araç-gereçleri yanında bulundurmama $(X=$ 3,09) ve M12 Sinff, kantin, soyunma odasl ve lavabolarl temiz kullanmama (X=3,08) davranışlarının en sık rastlanan disiplin problemleri olduğu anlaşılmaktadır.

Öğrenci görüşlerinin de daha çok Bazen düzeyinde yoğunlaştığı görülmektedir. Öğrenci görüşlerine göre araştırma kapsamındaki okullarda en çok; M1 Öğrencilerin giyim tarzlarının kllik-klyafet kurallarina uygun olmamasi $(X=3,26)$, M12 Sinif, kantin, soyunma odasl ve lavaboları temiz kullanmama $(X=3,21)$, M25 Koridor ve merdivenlerde birbirini itme, gürültü ve kargaşa yaşanması $(X=3,17)$, M15 Argo ve kaba ifadeler kullanma $(X=3,12)$ ve M23 Öğrencilere lakap takma $(X=3,09)$ davranışlarına rastlandığı anlaşılmaktadır. 
Tablo 4.

Öğretmen ve öğrenci görüsslerine göre okullardaki disiplin problemlerinin yaşanma sıklığının dağılımı

\begin{tabular}{|c|c|c|c|c|}
\hline \multirow[b]{2}{*}{ Madde } & \multicolumn{2}{|c|}{ Öğretmen } & \multicolumn{2}{|c|}{ Öğrenci } \\
\hline & Ort. & $\mathrm{S}$ & Ort. & $\mathrm{S}$ \\
\hline $\begin{array}{l}\text { M1 Öğrencilerin giyim tarzlarının kılık-kıyafet kurallarına } \\
\text { uygun olmaması }\end{array}$ & 3,11 & 0,97 & 3,26 & 1,17 \\
\hline $\begin{array}{l}\text { M2 Öğrencilerin yanlarında kesici ve delici aletler } \\
\text { bulundurması }\end{array}$ & 1,94 & 0,86 & 1,78 & 1,03 \\
\hline M3 Cep telefonu ve kamerayı kötü amaçlı kullanma & 2,14 & 1,02 & 1,95 & 1,17 \\
\hline M4 Okuldan kaçma & 2,64 & 0,92 & 2,75 & 1,28 \\
\hline M5 Törenler sırasında saygısız davranışlarda bulunma & 2,83 & 0,98 & 2,85 & 1,33 \\
\hline $\begin{array}{l}\text { M6 Okula geldiği halde kasıtlı olarak derslere, törenlere } \\
\text { katılmamak }\end{array}$ & 2,27 & 0,91 & 2,24 & 1,13 \\
\hline M7 Derse geç gelme & 2,89 & 0,81 & 2,83 & 1,04 \\
\hline $\begin{array}{l}\text { M8 Dersin akışını ve sınıf düzenini bozacak tavır ve } \\
\text { davranışlar sergileme }\end{array}$ & 3,10 & 0,96 & 3,03 & 1,26 \\
\hline M9 Dersle ilgili araç-gereçleri yanında bulundurmama & 3,09 & 0,90 & 2,76 & 1,13 \\
\hline M10 Sinavlarda kopya çekme & 2,61 & 0,91 & 2,98 & 1,35 \\
\hline M11 Okul binası, duvarları ve araç-gereçlerine zarar verme & 2,66 & 0,93 & 2,46 & 1,26 \\
\hline $\begin{array}{l}\text { M12 Sinıf, kantin, soyunma odası ve lavaboları temiz } \\
\text { kullanmama }\end{array}$ & 3,08 & 1,00 & 3,21 & 1,43 \\
\hline M13 Öğretmenlere karşı saygısız davranışlarda bulunma & 2,66 & 0,96 & 2,19 & 1,14 \\
\hline $\begin{array}{l}\text { M14 Yöneticilere, memurlara ve diğer görevlilere hakaret } \\
\text { etmek }\end{array}$ & 1,91 & 0,93 & 1,56 & ,97 \\
\hline M15 Argo ve kaba ifadeler kullanma & 2,79 & 1,05 & 3,12 & 1,34 \\
\hline $\begin{array}{l}\text { M16 Öğretmen veya okul yönetimi tarafından verilen } \\
\text { ödevleri ve görevleri yapmama }\end{array}$ & 2,83 & 0,93 & 2,63 & 1,06 \\
\hline M17 Kavga etme & 2,85 & 0,91 & 2,95 & 1,17 \\
\hline $\begin{array}{l}\text { M18 Yaşça büyük ya da güçlü öğrencilerin diğer öğrenciler } \\
\text { üzerinde baskı kurması }\end{array}$ & 2,68 & 0,97 & 2,80 & 1,40 \\
\hline M19 Çeteleşerek öğrencileri tehdit etme & 2,09 & 0,96 & 2,26 & 1,35 \\
\hline M20 Öğretmenlerle dalga geçme & 2,13 & 0,94 & 2,16 & 1,27 \\
\hline M21 Öğretmenlere lakap takma & 2,08 & 0,95 & 2,24 & 1,31 \\
\hline M22 Öğrencilerle dalga geçme & 2,72 & 1,04 & 3,00 & 1,37 \\
\hline M23 Öğrencilere lakap takma & 2,82 & 1,00 & 3,09 & 1,38 \\
\hline M24 Yalan söylemek & 2,94 & 0,93 & 2,97 & 1,30 \\
\hline $\begin{array}{l}\text { M25 Koridor ve merdivenlerde birbirini itme, gürültü ve } \\
\text { kargaşa yaşanması }\end{array}$ & 3,12 & 1,09 & 3,17 & 1,36 \\
\hline $\begin{array}{l}\text { M26 Okulla ilgisiz kişilerin okul içerisinde ve çevresinde } \\
\text { öğrencileri rahatsız etmesi }\end{array}$ & 2,10 & 0,97 & 2,32 & 1,37 \\
\hline M27 Başkasının malına zarar vermek & 2,36 & 0,90 & 2,31 & 1,22 \\
\hline $\begin{array}{l}\text { M28 Başkasının malını haberi olmadan almayı alışkanlık } \\
\text { hâline getirmek. }\end{array}$ & 2,20 & 0,89 & 2,21 & 1,31 \\
\hline
\end{tabular}

Tablo 5'te disiplin problemlerinin yaşanma sıklığı ile ilgili öğretmen ve öğrenci görüşleri arasındaki farklılaşmaya ilişkin $U$ testi sonuçları verilmiştir.

Yapılan Mann Whitney U testi sonucunda bazı disiplin problemlerinin yaşanma sıklığına ilişkin öğretmen $(\mathrm{n}=691)$ ve öğrenci $(\mathrm{n}=1001)$ görüşlerinin istatistiksel açıdan anlamlı biçimde farklılaştığı görülmüştür. Sira Ortalamaları incelendiğinde öğretmenler $M-2, M-3, M-6, M-9, M$ 11, $M-13, M-14, M-16, M-20, M-27, M-28^{\prime}$ de disiplin sorunlarının anlamlı düzeyde daha s1k yaşandığını düşünmektedir. Maddelere ilişkin hesaplanan etki değerlerinin M-13 Öğretmenlere karşı saygısız davranışlarda bulunma ( $\mathrm{U}=251011,5 ; \mathrm{p}<.05 ; \mathrm{r}=-0.24)$ ve M-14 Yöneticilere, memurlara ve diğer görevlilere hakaret etmek $(\mathrm{U}=250817 ; \mathrm{p}<.05 ; \mathrm{r}=-0.26)$ maddelerinde diğer maddelere göre daha yüksek olduğu saptanmıştır. Diğer taraftan öğretmenlerle karşılaştırıldığında öğrenci görüşlerinin $M-1, M-10, M-12, M-15, M-22, M-23$ maddelerinde anlamlı bir şekilde farklılaştığı görülmektedir. Ancak istatistiksel olarak anlamlı bulunan bu farklar için hesaplanan 
etki değerlerinin (r) küçük olması $(\leq .3)$, farkların pratikte manidarlığının sorgulanabilir olduğunu göstermektedir.

Tablo 5.

Disiplin problemlerinin yaşanma sıklı̆ğıa ile ilgili öğretmen $(n=691)$ ve öğrenci $(n=1001)$ görüşleri arasındaki farklılaşmaya ilişkin U testi sonuçları

\begin{tabular}{|c|c|c|c|c|c|c|}
\hline Madde & Statü & $\begin{array}{l}\text { Sira } \\
\text { Ort. }\end{array}$ & $\begin{array}{l}\text { Sira } \\
\text { Top. }\end{array}$ & $\mathrm{U}$ & $\mathrm{p}$ & $\mathrm{R}$ \\
\hline givim t & Öğrtm. & 802,03 & 554202,50 & 315116,5 & ,001* & -0.07 \\
\hline kıyafet kl & Öğrci. & 877,20 & 878075,50 & & & \\
\hline $\begin{array}{l}\text { M-2 Öğrencilerin yanlarında kesici ve } \\
\text { delici aletler bulundurması }\end{array}$ & $\begin{array}{l}\text { Öğrtm. } \\
\text { Öğrci. }\end{array}$ & $\begin{array}{l}925,37 \\
792,06\end{array}$ & $\begin{array}{l}639427,50 \\
792850,50\end{array}$ & 291349,5 &, $000 *$ & -0.14 \\
\hline $\begin{array}{l}\text { M-3 Cep telefonu ve kamerayı kötü amaçlı } \\
\text { kullanma }\end{array}$ & $\begin{array}{l}\text { Öğrtm. } \\
\text { Öğrci. }\end{array}$ & $\begin{array}{l}922,49 \\
794,05\end{array}$ & $\begin{array}{l}637438,00 \\
794840,00\end{array}$ & 293339,0 &, $000 *$ & -0.13 \\
\hline $\begin{array}{l}\text { M-6 Okula geldiği halde kasıtlı olarak } \\
\text { derslere, törenlere katılmamak }\end{array}$ & $\begin{array}{l}\text { Öğgrtm. } \\
\text { Öğrci. }\end{array}$ & $\begin{array}{l}874,68 \\
827,05\end{array}$ & $\begin{array}{l}604402,00 \\
827876,00\end{array}$ & 326375,0 &, $040^{*}$ & -0.05 \\
\hline $\begin{array}{l}\text { M-9 Dersle ilgili araç-gereçleri yanında } \\
\text { bulundurmama }\end{array}$ & $\begin{array}{l}\text { Öğrtm. } \\
\text { Öğrci. }\end{array}$ & $\begin{array}{l}940,50 \\
781,61\end{array}$ & $\begin{array}{l}649887,50 \\
782390,50\end{array}$ & 280889,5 &, $000 *$ & -0.16 \\
\hline M-10 Sinavlarda kopya çekme & $\begin{array}{l}\text { Öğrtm. } \\
\text { Öğrci. }\end{array}$ & $\begin{array}{l}769,66 \\
899,54\end{array}$ & $\begin{array}{l}531838,50 \\
900439,50\end{array}$ & 292752,5 &, $000 *$ & -0.13 \\
\hline $\begin{array}{l}\text { M-11 Okul binası, duvarları ve araç- } \\
\text { gereçlerine zarar verme }\end{array}$ & $\begin{array}{l}\text { Öğgrtm. } \\
\text { Öğrci. }\end{array}$ & $\begin{array}{l}915,45 \\
798,90\end{array}$ & $\begin{array}{l}632579,00 \\
799699,00\end{array}$ & 298198,0 &, $000 *$ & -0.12 \\
\hline $\begin{array}{l}\text { M-12 Sinıf, kantin, soyunma odası ve } \\
\text { lavaboları temiz kullanmama }\end{array}$ & $\begin{array}{l}\text { Öğrtm. } \\
\text { Öğrci. }\end{array}$ & $\begin{array}{l}814,05 \\
868,90\end{array}$ & $\begin{array}{l}562512,00 \\
869766,00\end{array}$ & 323426,0 &, $020^{*}$ & -0.05 \\
\hline $\begin{array}{l}\text { M-13 Öğretmenlere karşı saygısız } \\
\text { davranışlarda bulunma }\end{array}$ & $\begin{array}{l}\text { Öğrtm. } \\
\text { Öğrci. }\end{array}$ & $\begin{array}{l}983,74 \\
751,76\end{array}$ & $\begin{array}{l}679765,50 \\
752512,50\end{array}$ & 251011,5 &, $000 *$ & -0.24 \\
\hline $\begin{array}{l}\text { M-14 Yöneticilere, memurlara ve diğer } \\
\text { görevlilere hakaret etmek }\end{array}$ & $\begin{array}{l}\text { Öğgrtm. } \\
\text { Öğrci. }\end{array}$ & $\begin{array}{l}984,02 \\
751,57\end{array}$ & $\begin{array}{l}679960,00 \\
752318,00\end{array}$ & 250817,0 &, $000 *$ & -0.26 \\
\hline M-15 Argo ve kaba ifadeler kullanma & $\begin{array}{l}\text { Öğgrtm. } \\
\text { Öğrci. }\end{array}$ & $\begin{array}{l}776,26 \\
894,99\end{array}$ & $\begin{array}{l}536395,00 \\
895883,00\end{array}$ & 297309,0 &, $000 *$ & -0.12 \\
\hline $\begin{array}{l}\text { M-16 Öğretmen-okul yönetimi tarafindan } \\
\text { verilen ödevleri ve görevleri yapmama }\end{array}$ & $\begin{array}{l}\text { Öğrtm. } \\
\text { Öğrci. }\end{array}$ & $\begin{array}{l}906,11 \\
805,35\end{array}$ & $\begin{array}{l}626121,50 \\
806156,50\end{array}$ & 304655,5 &, $000 *$ & -0.10 \\
\hline M-20 Öğretmenlerle dalga geçme & $\begin{array}{l}\text { Öğgrtm. } \\
\text { Öğrci. }\end{array}$ & $\begin{array}{l}874,95 \\
826,86\end{array}$ & $\begin{array}{l}604593,50 \\
827684,50\end{array}$ & 326183,5 &, $037^{*}$ & -0.05 \\
\hline M-22 Öğrencilerle dalga geçme & $\begin{array}{l}\text { Öğrtm. } \\
\text { Öğrci. }\end{array}$ & $\begin{array}{l}795,53 \\
881,69\end{array}$ & $\begin{array}{l}549709,50 \\
882568,50\end{array}$ & 310623,5 &, $000 *$ & -0.08 \\
\hline M-23 Öğrencilere lakap takma & $\begin{array}{l}\text { Öğrtm. } \\
\text { Öğrci. }\end{array}$ & $\begin{array}{l}791,25 \\
884,64\end{array}$ & $\begin{array}{l}546756,00 \\
885522,00\end{array}$ & 307670,0 &, $000 *$ & -0.09 \\
\hline M-27 Başkasının malına zarar vermek & $\begin{array}{l}\text { Öğrtm. } \\
\text { Öğrci. }\end{array}$ & $\begin{array}{l}883,17 \\
821,19\end{array}$ & $\begin{array}{l}610271,00 \\
822007,00\end{array}$ & 320506,0 &, $008 *$ & -0.06 \\
\hline $\begin{array}{l}\text { M-28 Başkasının malını haberi olmadan } \\
\text { almayı alışkanlık hâline getirmek. }\end{array}$ & $\begin{array}{l}\text { Öğrtm. } \\
\text { Öğrci. }\end{array}$ & $\begin{array}{l}888,67 \\
817,39\end{array}$ & $\begin{array}{l}614073,00 \\
818205,00\end{array}$ & 316704,0 &, $002 *$ & -0.07 \\
\hline
\end{tabular}

Tablo 6'da disiplin problemlerinin yaşanma sıklığına ile ilgili öğretmen ve öğrenci görüşlerinin eğitim kademesine göre farklılaşmasına ilişkin $U$ testi sonuçları sunulmaktadır. Yapılan Mann Whitney U testi sonucunda bazı disiplin problemlerinin eğitim kademesine göre ortaokul $(n=414)$ ve liselerde $(n=277)$ yaşanma sıklığına ilişkin öğretmen görüşleri arasında istatistiksel açıdan anlamlı farklılaşmalara rastlanmıştır. Sıra ortalamaları incelendiğinde öğretmenler M-2 M-5 M-8 M-17 M-18 M-19 M-22 M-23 M-24 M-25 M-27 maddelerdeki davranışların ortaokulda anlamlı düzeyde daha sık yaşandığını düşünmektedir.

Sıra ortalamaları incelendiğinde M-25 Koridor ve merdivenlerde birbirini itme, gürültü ve kargaşa yaşanması $(\mathrm{U}=36602 ; \mathrm{p}<.05 ; \mathrm{r}=-.31)$ maddesinde ortaokul öğretmenlerinin görüşleri liselerde çalışan ögretmenlere göre anlamlı bir şekilde farklılaştığı görülmektedir. Bu maddeye 
iliş̧kin etki değerinin ( $r>3$ ) orta düzeyde olması bu farkın pratikte manidar olduğunu göstermektedir.

Sıra Ortalamaları incelendiğinde öğretmenler M-3, M-4, M-10 ve M-21'deki davranışların liselerde anlamlı düzeyde daha sık yaşandığını düşünmektedir:

M-3 Cep telefonu ve kamerayı kötü amaçlı kullanma ( $\mathrm{U}=39167 ; \mathrm{p}<.05 ; \mathrm{r}=-.28)$; maddesinde liselerde çalışan öğretmenlerin görüşleri ortaokul öğretmenlerine göre anlamlı bir şekilde farklılaşmaktadır. Hesaplanan etki değerleri incelendiğinde, cep telefonu ve kamerayı kötü amaçlı kullanma $(\mathrm{r}=.28)$ davranışı için bu farkın etki büyüklügünün orta düzeye yakın olduğundan ( $r>3)$ dolayı nispeten dikkate alınabileceği söylenebilir. Diğer farklar için hesaplanan etki büyüklükleri ise küçük oldukları için $(\leq .3)$, bu farkların pratikte manidarlığı sorgulanabilirdir. Bu maddeler dışındaki disiplin problemlerinin yaşanma sıklığına ilişkin istatistiksel açıdan anlamlı bir fark bulunamaması ( $p>.05$ ) hem ortaokul hem de ve liselerde görev yapan öğretmenlerin bu disiplin problemlerin yaşanma sıklığına ilişkin benzer görüşlere sahip oldukları şekilde yorumlanabilir.

Tablo 6.

Disiplin problemlerinin yaşanma sıklığına göre öğretmen $(n=691)$ görüşlerinin eğitim kademesine göre farklılaşmasına ilişkin U testi sonuçları

\begin{tabular}{|c|c|c|c|c|c|c|}
\hline Madde & $\begin{array}{c}\text { Eğitim } \\
\text { kademesi }\end{array}$ & $\begin{array}{l}\text { Sira } \\
\text { Ort. }\end{array}$ & $\begin{array}{l}\text { Sira } \\
\text { Top. }\end{array}$ & $\mathrm{U}$ & $\mathrm{p}$ & $\mathrm{r}$ \\
\hline \multirow{4}{*}{$\begin{array}{l}\text { M-2 Öğrencilerin yanlarında kesici } \\
\text { ve delici aletler bulundurması } \\
\text { M-3 Cep telefonu ve kamerayı kötü } \\
\text { amaçlı kullanma }\end{array}$} & Ortaokul & 359,32 & 148759,00 & \multirow[t]{2}{*}{51824,0} & \multirow[t]{2}{*}{, $020 *$} & \multirow[t]{2}{*}{-0.08} \\
\hline & Lise & 326,09 & 90327,00 & & & \\
\hline & Ortaokul & 302,11 & 125072,00 & \multirow[t]{2}{*}{39167,0} & \multirow[t]{2}{*}{, $000 *$} & \multirow[t]{2}{*}{-0.28} \\
\hline & Lise & 411,60 & 114014,00 & & & \\
\hline \multirow[t]{2}{*}{ M-4 Okuldan kaçma } & Ortaokul & 317,13 & 131293,00 & \multirow[t]{2}{*}{45388,0} & \multirow[t]{2}{*}{, $000 *$} & \multirow[t]{2}{*}{-0.18} \\
\hline & Lise & 389,14 & 107793,00 & & & \\
\hline \multirow{2}{*}{$\begin{array}{l}\text { M-5Törenler sirasında saygısız } \\
\text { davranışlarda bulunma }\end{array}$} & Ortaokul & 382,25 & 158249,50 & \multirow[t]{2}{*}{42333,5} & \multirow[t]{2}{*}{, $000 *$} & \multirow[t]{2}{*}{-0.23} \\
\hline & Lise & 291,83 & 80836,50 & & & \\
\hline \multirow{2}{*}{$\begin{array}{l}\text { M-8 Dersin akışını ve sınıf düzenini } \\
\text { bozacak tavır ve davranışlar } \\
\text { sergileme }\end{array}$} & Ortaokul & 368,08 & 152384,50 & \multirow[t]{2}{*}{48198,5} & \multirow[t]{2}{*}{, $000 *$} & \multirow[t]{2}{*}{0.14} \\
\hline & Lise & 313,00 & 86701,50 & & & \\
\hline \multirow[t]{2}{*}{ M-10 Sinavlarda kopya çekme } & Ortaokul & 321,34 & 133036,50 & \multirow[t]{2}{*}{47131,5} & \multirow[t]{2}{*}{, $000 *$} & \multirow[t]{2}{*}{0.16} \\
\hline & Lise & 382,85 & 106049,50 & & & \\
\hline \multirow[t]{2}{*}{ M-17 Kavga etme } & Ortaokul & 373,34 & 154562,00 & \multirow[t]{2}{*}{46021,0} & \multirow[t]{2}{*}{, $000 *$} & \multirow[t]{2}{*}{-0.17} \\
\hline & Lise & 305,14 & 84524,00 & & & \\
\hline \multirow{2}{*}{$\begin{array}{l}\text { M-18 Yaşça büyük ya da güçlü } \\
\text { öğrencilerin diğer } \\
\text { üzerinde baskı kurması }\end{array}$} & Ortaokul & 370,97 & 153581,50 & \multirow[t]{2}{*}{47001,5} & \multirow[t]{2}{*}{, $000 *$} & -0.16 \\
\hline & Lise & 308,68 & 85504,50 & & & \\
\hline M-19 Çeteleşerek öğrencileri tehdit & Ortaokul & 357,56 & 148030,50 & 52552,5 &, $049 *$ & -0.07 \\
\hline etme & Lise & 328,72 & 91055,50 & & & \\
\hline M-21 Öğretmenlere lakap takma & Ortaokul & 330,94 & 137010,50 & 51105,5 &, $010 *$ & -0.09 \\
\hline & Lise & 368,50 & 102075,50 & & & \\
\hline M-22 Öğrencilerle dalga geçme & Ortaokul & 358,57 & 148449,00 & 52134,0 &, $035^{*}$ & -0.08 \\
\hline & Lise & 327,21 & 90637,00 & & & \\
\hline M-23 Öğrencilere lakap takma & Ortaokul & 369,88 & 153130,50 & 47452,5 &, $000 *$ & -0.15 \\
\hline & Lise & 310,31 & 85955,50 & & & \\
\hline M-24 Yalan söylemek & Ortaokul & 364,18 & 150771,50 & 49811,5 &, $002 *$ & -0.11 \\
\hline & Lise & 318,82 & 88314,50 & & & \\
\hline M-25 Koridor ve merdivenlerde & Ortaokul & 396,09 & 163981,00 & 36602,0 &, $000 *$ & -0.31 \\
\hline $\begin{array}{l}\text { birbirini itme, gürültü ve kargaşa } \\
\text { yaşanması }\end{array}$ & Lise & 271,14 & 75105,00 & & & \\
\hline M-27 Başkasının malına zarar & Ortaokul & 370,36 & 153328,00 & 47255,0 &, $000 *$ & -0.15 \\
\hline vermek & Lise & 309,60 & 85758,00 & & & \\
\hline
\end{tabular}

Tablo 7'de disiplin problemlerinin yaşanma sıklığına ilişkin öğretmen $(n=277)$ görüşlerinin lise türüne göre farklılaşıp farklılaşmadığını gösteren Kruskal Wallis testi sonuçları 
sunulmuştur. Bulgular lise türüne göre incelendiğinde öğretmen görüşlerinin bütün maddelerde anlamlı düzeyde farklılıklar gösterdiği anlaşılmaktadır. Analiz sonuçlarında sıra ortalamalarına bakıldığında anket sorularında belirtilen disiplin problemlerinin tamamında Mesleki ve Teknik Liselerin en yüksek puanı aldığı görülmektedir. Bu durumda, araştırmaya katılan öğretmen görüşlerine göre Mesleki ve Teknik Liselerde belirtilen disiplin problemlerinin yaşanma sıklığının diğer lise türlerine göre daha yüksek olduğu anlaşılmaktadır.

Tablo 7.

Liselerde disiplin problemlerinin yaşanma sıklığına dair öğretmen $(n=277)$ görüşlerinin lisenin türüne göre farklılaşmasına ilişkin Kruskal Wallis testi sonuçları

\begin{tabular}{|c|c|c|c|c|c|c|c|}
\hline Madde & Okul Türü & $\mathrm{n}$ & $\begin{array}{c}\text { Sira } \\
\text { ort. }\end{array}$ & sd & $X^{2}$ & $\mathrm{p}$ & FARK (U) \\
\hline \multirow{3}{*}{$\begin{array}{l}\text { M-1 Öğrencilerin giyim tarzlarının } \\
\text { kılık-kıyafet kurallarına uygun } \\
\text { olmaması }\end{array}$} & 1) Ana. L. & 113 & 127,45 & 2 & 23,258 &, $000 *$ & $1>2(r=-0.19)$ \\
\hline & 2) Fen & 35 & 96,59 & & & & $3>1(r=-0.22)$ \\
\hline & 3) Meslek & 129 & 160,63 & & & & $3>2(r=-0.33)$ \\
\hline \multirow{3}{*}{$\begin{array}{l}\text { M-2 Öğrencilerin yanlarında kesici } \\
\text { ve delici aletler bulundurması }\end{array}$} & 1) Ana. L. & 113 & 118,27 & 2 & 48,621 &, $000 *$ & $1>2(r=-0.20)$ \\
\hline & 2) Fen & 35 & 88,13 & & & & $3>1(r=-0.36)$ \\
\hline & 3) Meslek & 129 & 170,97 & & & & $3>2(r=-0.44)$ \\
\hline \multirow{3}{*}{$\begin{array}{l}\text { M-3 Cep telefonu ve kamerayı } \\
\text { kötü amaçlı kullanma }\end{array}$} & 1) Ana. L. & 113 & 124,99 & 2 & 20,797 &, $000 *$ & $3>1(r=-0.24)$ \\
\hline & 2) Fen & 35 & 104,61 & & & & $3>2(r=-0.28)$ \\
\hline & 3) Meslek & 129 & 160,60 & & & & \\
\hline \multirow[t]{3}{*}{ M-4 Okuldan kaçma } & 1) Ana. L. & 113 & 112,46 & 2 & 66,592 &, $000 *$ & $1>2(r=-0.19)$ \\
\hline & 2) Fen & 35 & 82,70 & & & & $3>1(r=-0.43)$ \\
\hline & 3) Meslek & 129 & 177,53 & & & & $3>2(r=-0.50)$ \\
\hline \multirow{3}{*}{$\begin{array}{l}\text { M-5 Törenler sırasında saygısız } \\
\text { davranışlarda bulunma }\end{array}$} & 1) Ana. L. & 113 & 123,12 & 2 & 33,573 &, $000 *$ & $1>2(r=-0.19)$ \\
\hline & 2) Fen & 35 & 92,80 & & & & $3>1(r=-0.28)$ \\
\hline & 3) Meslek & 129 & 165,45 & & & & $3>2(r=-0.38)$ \\
\hline \multirow{3}{*}{$\begin{array}{l}\text { M-6 Okula geldiği halde kasıtlı } \\
\text { olarak derslere, törenlere } \\
\text { katılmamak, }\end{array}$} & 1) Ana. L. & 113 & 130,26 & 2 & 26,020 &, $000 *$ & $1>2(r=-0.22)$ \\
\hline & 2) Fen & 35 & 89,93 & & & & $3>1(r=-0.19)$ \\
\hline & 3) Meslek & 129 & 159,97 & & & & $3>2(r=-0.38)$ \\
\hline \multirow[t]{3}{*}{ M-7 Derse geç gelme } & 1) Ana. L. & 113 & 119,55 & 2 & 21,617 &, $000 *$ & $3>1(r=-0.28)$ \\
\hline & 2) Fen & 35 & 118,90 & & & & $3>2(r=-0.24)$ \\
\hline & 3) Meslek & 129 & 161,49 & & & & \\
\hline \multirow{3}{*}{$\begin{array}{l}\text { M-8 Dersin akışını ve sınıf } \\
\text { düzenini bozacak tavır ve } \\
\text { davranışlar sergileme }\end{array}$} & 1) Ana. L. & 113 & 121,15 & 2 & 36,866 &, $000 *$ & $1>2(r=-0.17)$ \\
\hline & 2) Fen & 35 & 92,54 & & & & $3>1(r=-0.30)$ \\
\hline & 3) Meslek & 129 & 167,24 & & & & $3>2(r=-0.39)$ \\
\hline \multirow{3}{*}{$\begin{array}{l}\text { M-9 Dersle ilgili araç-gereçleri } \\
\text { yanında bulundurmama }\end{array}$} & 1) Ana. L. & 113 & 119,61 & 2 & 57,603 &, $000 *$ & $1>2(r=-0.30)$ \\
\hline & 2) Fen & 35 & 75,29 & & & & $3>1(r=-0.36)$ \\
\hline & 3) Meslek & 129 & 173,27 & & & & $3>2(r=-0.50)$ \\
\hline \multirow[t]{3}{*}{ M-10 Sınavlarda kopya çekme } & 1) Ana. L. & 113 & 122,03 & 2 & 29,901 &, $000 *$ & $3>1(r=-0.28)$ \\
\hline & 2) Fen & 35 & 99,47 & & & & $3>2(r=-0.34)$ \\
\hline & 3) Meslek & 129 & 164,59 & & & & \\
\hline \multirow{3}{*}{$\begin{array}{l}\text { M-11 Okul binası, duvarları ve } \\
\text { araç-gereçlerine zarar verme }\end{array}$} & 1) Ana. L. & 113 & 122,35 & 2 & 28,780 &, $000 *$ & $3>1(r=-0.28)$ \\
\hline & 2) Fen & 35 & 100,37 & & & & $3>2(r=-0.33)$ \\
\hline & 3) Meslek & 129 & 164,06 & & & & \\
\hline \multirow{3}{*}{$\begin{array}{l}\text { M-12 Sinıf, kantin, soyunma odası } \\
\text { ve lavaboları temiz kullanmama }\end{array}$} & 1) Ana. L. & 113 & 123,83 & 2 & 26,160 &, $000 *$ & $3>1(r=-0.26)$ \\
\hline & 2) Fen & 35 & 99,20 & & & & $3>2(r=-0.32)$ \\
\hline & 3) Meslek & 129 & 163,09 & & & & \\
\hline
\end{tabular}




\begin{tabular}{|c|c|c|c|c|c|c|c|}
\hline \multirow{3}{*}{$\begin{array}{l}\text { M-13 Öğretmenlere karşı saygısız } \\
\text { davranışlarda bulunma }\end{array}$} & 1) Ana. L. & 113 & 120,06 & 2 & 40,658 &, $000 *$ & $1>2(r=-0.19)$ \\
\hline & 2) Fen & 35 & 90,43 & & & & $3>1(\mathrm{r}=-0.32)$ \\
\hline & 3) Meslek & 129 & 168,77 & & & & $3>2(r=-0.40)$ \\
\hline \multirow{3}{*}{$\begin{array}{l}\text { M-14 Yöneticilere, memurlara ve } \\
\text { diğer görevlilere hakaret etmek }\end{array}$} & 1) Ana. L. & 113 & 118,69 & 2 & 33,734 &, $000 *$ & $3>1(r=-0.31)$ \\
\hline & 2) Fen & 35 & 102,66 & & & & $3>2(r=-0.34)$ \\
\hline & 3) Meslek & 129 & 166,65 & & & & \\
\hline \multirow{3}{*}{$\begin{array}{l}\text { M-15 Argo ve kaba ifadeler } \\
\text { kullanma }\end{array}$} & 1) Ana. L. & 113 & 116,65 & 2 & 54,476 &, $000 *$ & $1>2(r=-0.25)$ \\
\hline & 2) Fen & 35 & 83,11 & & & & $3>1(r=-0.38)$ \\
\hline & 3) Meslek & 129 & 173,74 & & & & $3>2(r=-0.44)$ \\
\hline \multirow{3}{*}{$\begin{array}{l}\text { M-16 Öğretmen veya okul } \\
\text { yönetimi tarafından verilen } \\
\text { ödevleri ve görevleri yapmama }\end{array}$} & 1) Ana. L. & 113 & 121,68 & 2 & 49,808 &, $000 *$ & $1>2(r=-0.28)$ \\
\hline & 2) Fen & 35 & 78,26 & & & & $3>1(r=-0.33)$ \\
\hline & 3) Meslek & 129 & 170,66 & & & & $3>2(r=-0.47)$ \\
\hline \multirow[t]{3}{*}{ M-17 Kavga etme } & 1) Ana. L. & 113 & 115,87 & 2 & 60,275 &, $000 *$ & $1>2(r=-0.21)$ \\
\hline & 2) Fen & 35 & 81,57 & & & & $3>1(r=-0.39)$ \\
\hline & 3) Meslek & 129 & 174,84 & & & & $3>2(r=-0.50)$ \\
\hline \multirow{3}{*}{$\begin{array}{l}\text { M-18 Yaşça büyük ya da güçlü } \\
\text { öğrencilerin diğer öğrenciler } \\
\text { üzerinde baskı kurması }\end{array}$} & 1) Ana. L. & 113 & 115,56 & 2 & 52,162 &, $000 *$ & $1>2(r=-0.16)$ \\
\hline & 2) Fen & 35 & 88,63 & & & & $3>1(r=-0.38)$ \\
\hline & 3) Meslek & 129 & 173,20 & & & & $3>2(r=-0.45)$ \\
\hline \multirow{3}{*}{$\begin{array}{l}\text { M-19 Çeteleşerek öğrencileri } \\
\text { tehdit etme }\end{array}$} & 1) Ana. L. & 113 & 120,10 & 2 & 47,846 &, $000 *$ & $1>2(r=-0.24)$ \\
\hline & 2) Fen & 35 & 83,69 & & & & $3>1(r=-0.34)$ \\
\hline & 3) Meslek & 129 & 170,57 & & & & $3>2(r=-0.44)$ \\
\hline \multirow[t]{3}{*}{ M-20 Öğretmenlerle dalga geçme } & 1) Ana. L. & 113 & 126,39 & 2 & 26,630 &, $000 *$ & $1>2(r=-0.18)$ \\
\hline & 2) Fen & 35 & 95,41 & & & & $3>1(r=-0.24)$ \\
\hline & 3) Meslek & 129 & 161,87 & & & & $3>2(r=-0.35)$ \\
\hline \multirow[t]{3}{*}{ M-21 Öğretmenlere lakap takma } & 1) Ana. L. & 113 & 129,46 & 2 & 20,331 &, $000 *$ & $1>2(r=-0.19)$ \\
\hline & 2) Fen & 35 & 98,89 & & & & $3>1(r=-0.19)$ \\
\hline & 3) Meslek & 129 & 158,24 & & & & $3>2(r=-0.31)$ \\
\hline \multirow[t]{3}{*}{ M-22 Öğrencilerle dalga geçme } & 1) Ana. L. & 113 & 121,74 & 2 & 33,734 &, $000 *$ & $1>2(r=-0.16)$ \\
\hline & 2) Fen & 35 & 94,43 & & & & $3>1(r=-0.29)$ \\
\hline & 3) Meslek & 129 & 166,21 & & & & $3>2(r=-0.37)$ \\
\hline \multirow[t]{3}{*}{ M-23 Öğrencilere lakap takma } & 1) Ana. L. & 113 & 123,15 & 2 & 32,876 &, $000 *$ & $1>2(r=-0.18)$ \\
\hline & 2) Fen & 35 & 93,07 & & & & $3>1(r=-0.27)$ \\
\hline & 3) Meslek & 129 & 165,35 & & & & $3>2(r=-0.38)$ \\
\hline \multirow[t]{3}{*}{ M-24 Yalan söylemek } & 1) Ana. L. & 113 & 121,49 & 2 & 30,988 &, $000 *$ & $3>1(r=-0.28)$ \\
\hline & 2) Fen & 35 & 98,79 & & & & $3>2(r=-0.36)$ \\
\hline & 3) Meslek & 129 & 165,25 & & & & \\
\hline \multirow{3}{*}{$\begin{array}{l}\text { M-25 Koridor ve merdivenlerde } \\
\text { birbirini itme, gürültü ve kargaşa } \\
\text { yaşanması }\end{array}$} & 1) Ana. L. & 113 & 111,56 & 2 & 76,220 &, $000 *$ & $1>2(r=-0.27)$ \\
\hline & 2) Fen & 35 & 74,47 & & & & $3>1(r=-0.46)$ \\
\hline & 3) Meslek & 129 & 180,54 & & & & $3>2(r=-0.51)$ \\
\hline \multirow{3}{*}{$\begin{array}{l}\text { M-26 Okulla ilgisiz kişilerin okul } \\
\text { içerisinde ve çevresinde } \\
\text { öğrencileri rahatsı etmesi }\end{array}$} & 1) Ana. L. & 113 & 116,73 & 2 & 57,818 &, $000 *$ & $1>2(r=-0.24)$ \\
\hline & 2) Fen & 35 & 80,66 & & & & $3>1(r=-0.38)$ \\
\hline & 3) Meslek & 129 & 174,34 & & & & $3>2(r=-0.48)$ \\
\hline \multirow{3}{*}{$\begin{array}{l}\text { M-27 Başkasının malına zarar } \\
\text { vermek }\end{array}$} & 1) Ana. L. & 113 & 124,12 & 2 & 53,492 &, $000 *$ & $1>2(r=-0.34)$ \\
\hline & 2) Fen & 35 & 72,57 & & & & $3>1(r=-0.32)$ \\
\hline & 3) Meslek & 129 & 170,06 & & & & $3>2(r=-0.48)$ \\
\hline
\end{tabular}


M-28 Başkasının malını haberi olmadan almayı alışkanlık hâline getirmek.

$\begin{array}{lrrrrrr}\text { 1) Ana. L. } & 113 & 122,07 & 2 & 58,163,000^{*} & 1>2(r=-0.33) \\ \text { 2) Fen } & 35 & 71,70 & & & 3>1(r=-0.34) \\ \text { 3) Meslek } & 129 & 172,09 & & 3>2(r=-0.50)\end{array}$

$* \mathrm{p}<.05$

İkili karşılaştırmalarda istatistiksel olarak anlamlı bulunan bu farklar için hesaplanan etki değerlerine bakıldığında $M-9$ Dersle ilgili araç-gereçleri yanında bulundurmama ( $r=-0.30), M$ 27 Başkasının malına zarar vermek $(r=-0.34)$ ve $M-28$ Başkasının malını haberi olmadan almayı alışkanlık hâline getirmek ( $r=-0.33)$ davranışlarının orta düzeyde etki değeri $(\mathrm{r}=-0.35)$ olduğu ve bu davranışın yaşanma sıklığına ilişkin öğretmen görüşlerinin pratikte manidar olduğu görülmektedir. Buna göre belirtilen disiplin sorunlarının Anadolu liselerinde Fen Liselerine oranla daha sık yaşandığı anlaşılmaktadır. Diğer maddeler için yapılan ikili karşılaştırmalarda hesaplanan etki değerlerine bakıldığında istatistiksel olarak anlamlı bulunan bu farklar için hesaplanan etki değerlerinin (r) küçük olması ( $\leq .3)$, farkların pratikte manidarlığının sorgulanabilir olduğunu göstermektedir.

Tablo 8'de disiplin problemlerinin yaşanma sıklığına ilişkin öğrenci $(n=400)$ görüşlerinin lise türüne göre farklılaşıp farklılaşmadığını gösteren Kruskal Wallis testi sonuçları sunulmuştur. Yapılan Kruskal Wallis testi sonucunda lise türüne göre öğrenci görüşleri bütün maddelerde anlamlı düzeyde farklılıklar göstermektedir.

Tablo 8.

Liselerde disiplin problemlerinin yaşanma sıklığına dair öğrenci $(n=532)$ görüşlerinin lisenin türüne göre farklılaşmasına ilişkin Kruskal Wallis testi sonuçları

\begin{tabular}{|c|c|c|c|c|c|c|c|}
\hline Madde & Okul Türü & $\mathrm{N}$ & $\begin{array}{l}\text { Sira } \\
\text { ort. }\end{array}$ & sd & $X^{2}$ & $\mathrm{P}$ & FARK (U) \\
\hline \multirow{3}{*}{$\begin{array}{l}\text { M-1 Öğrencilerin giyim tarzlarının } \\
\text { k1lık-kıyafet kurallarına uygun } \\
\text { olmaması }\end{array}$} & 1) Ana. L. & 237 & 268,55 & 2 & 10,137 & ,006* & $1>2(r=-0.12)$ \\
\hline & 2) Fen & 109 & 228,75 & & & & $3>2(r=-0.18)$ \\
\hline & 3) Meslek & 186 & 286,01 & & & & \\
\hline \multirow{3}{*}{$\begin{array}{l}\text { M-2 Öğrencilerin yanlarında kesici } \\
\text { ve delici aletler bulundurması }\end{array}$} & 1) Ana. L. & 237 & 265,14 & 2 & 25,026 &, $000 *$ & $1>2(r=-0.17)$ \\
\hline & 2) Fen & 109 & 214,22 & & & & $3>1(r=-0.11)$ \\
\hline & 3) Meslek & 186 & 298,87 & & & & $3>2(r=-0.30)$ \\
\hline \multirow{3}{*}{$\begin{array}{l}\text { M-3 Cep telefonu ve kamerayı kötü } \\
\text { amaçlı kullanma }\end{array}$} & 1) Ana. L. & 237 & 290,34 & 2 & 11,398 &, $003 *$ & $1>2(r=-0.15)$ \\
\hline & 2) Fen & 109 & 245,01 & & & & $1>3(r=-0.14)$ \\
\hline & 3) Meslek & 186 & 248,72 & & & & \\
\hline \multirow[t]{3}{*}{ M-4 Okuldan kaçma } & 1) Ana. L. & 237 & 275,65 & 2 & 38,124 &, $000 *$ & $1>2(r=-0.27)$ \\
\hline & 2) Fen & 109 & 190,47 & & & & $3>2(r=-0.34)$ \\
\hline & 3) Meslek & 186 & 299,40 & & & & \\
\hline \multirow{3}{*}{$\begin{array}{l}\text { M-5 Törenler sırasında saygısız } \\
\text { davranışlarda bulunma }\end{array}$} & 1) Ana. L. & 237 & 280,19 & 2 & 14,835 &, $001 *$ & $1>2(r=-0.20)$ \\
\hline & 2) Fen & 109 & 217,44 & & & & $3>2(r=-0.19)$ \\
\hline & 3) Meslek & 186 & 277,80 & & & & \\
\hline \multirow{3}{*}{$\begin{array}{l}\text { M-6 Okula geldiği halde kasıtlı } \\
\text { olarak derslere, törenlere } \\
\text { katılmamak, }\end{array}$} & 1) Ana. L. & 237 & 264,31 & 2 & 5,547 &, 062 & \\
\hline & 2) Fen & 109 & 242,13 & & & & \\
\hline & 3) Meslek & 186 & 283,58 & & & & \\
\hline \multirow[t]{3}{*}{ M-7 Derse geç gelme } & 1) Ana. L. & 237 & 266,57 & 2 & 6,809 &, $033 *$ & $3>2(r=-0.15)$ \\
\hline & 2) Fen & 109 & 237,22 & & & & \\
\hline & 3) Meslek & 186 & 283,57 & & & & \\
\hline \multirow{3}{*}{$\begin{array}{l}\text { M-8 Dersin akışını ve sınıf } \\
\text { düzenini bozacak tavır ve } \\
\text { davranışlar sergileme }\end{array}$} & 1) Ana. L. & 237 & 281,22 & 2 & 10,563 &, $005 *$ & $1>2(r=-0.18)$ \\
\hline & 2) Fen & 109 & 225,80 & & & & $3>2(r=-0.14)$ \\
\hline & 3) Meslek & 186 & 271,60 & & & & \\
\hline
\end{tabular}




\begin{tabular}{|c|c|c|c|c|c|c|c|}
\hline \multirow{3}{*}{$\begin{array}{l}\text { M-9 Dersle ilgili araç-gereçleri } \\
\text { yanında bulundurmama }\end{array}$} & 1) Ana. L. & 237 & 274,85 & 2 & 21,535 &, $000^{*}$ & $1>2(r=-0.22)$ \\
\hline & 2) Fen & 109 & 208,91 & & & & $3>2(r=-0.24)$ \\
\hline & 3) Meslek & 186 & 289,61 & & & & \\
\hline \multirow[t]{3}{*}{ M-10 Sınavlarda kopya çekme } & 1) Ana. L. & 237 & 271,59 & 2 & 16,092 &, $000 *$ & $1>2(r=-0.17)$ \\
\hline & 2) Fen & 109 & 217,28 & & & & $3>2(r=-0.22)$ \\
\hline & 3) Meslek & 186 & 288,86 & & & & \\
\hline \multirow{3}{*}{$\begin{array}{l}\text { M-11 Okul binası, duvarları ve } \\
\text { araç-gereçlerine zarar verme }\end{array}$} & 1) Ana. L. & 237 & 265,54 & 2 & 13,573 &, $001 *$ & $1>2(r=-0.13)$ \\
\hline & 2) Fen & 109 & 225,81 & & & & $3>2(r=-0.21)$ \\
\hline & 3) Meslek & 186 & 291,57 & & & & \\
\hline \multirow{3}{*}{$\begin{array}{l}\text { M-12 Sinıf, kantin, soyunma odası } \\
\text { ve lavaboları temiz kullanmama }\end{array}$} & 1) Ana. L. & 237 & 264,12 & 2 & 7,549 &, $023 *$ & $3>2(r=-0.15)$ \\
\hline & 2) Fen & 109 & 237,20 & & & & \\
\hline & 3) Meslek & 186 & 286,70 & & & & \\
\hline \multirow{3}{*}{$\begin{array}{l}\text { M-13 Öğretmenlere karşı saygısıı } \\
\text { davranışlarda bulunma }\end{array}$} & 1) Ana. L. & 237 & 266,84 & 2 & 26,828 &, $000 *$ & $1>2(r=-0.19)$ \\
\hline & 2) Fen & 109 & 208,42 & & & & $3>1(r=-0.11)$ \\
\hline & 3) Meslek & 186 & 300,11 & & & & $3>2(r=-0.30)$ \\
\hline \multirow{3}{*}{$\begin{array}{l}\text { M-14 Yöneticilere, memurlara ve } \\
\text { diğer görevlilere hakaret etmek }\end{array}$} & 1) Ana. L. & 237 & 253,79 & 2 & 15,992 &, $000 *$ & $3>1(r=-0.16)$ \\
\hline & 2) Fen & 109 & 243,42 & & & & $3>2(r=-0.19)$ \\
\hline & 3) Meslek & 186 & 296,22 & & & & \\
\hline \multirow{3}{*}{$\begin{array}{l}\text { M-15 Argo ve kaba ifadeler } \\
\text { kullanma }\end{array}$} & 1) Ana. L. & 237 & 277,29 & 2 & 12,856 &, $002 *$ & $1>2(\mathrm{r}=-0.18)$ \\
\hline & 2) Fen & 109 & 220,68 & & & & $3>2(r=-0.17)$ \\
\hline & 3) Meslek & 186 & 279,60 & & & & \\
\hline \multirow{3}{*}{$\begin{array}{l}\text { M-16 Öğretmen veya okul } \\
\text { yönetimi tarafından verilen } \\
\text { ödevleri ve görevleri yapmama }\end{array}$} & 1) Ana. L. & 237 & 281,42 & 2 & 9,884 &, $007 *$ & $1>2(r=-0.18)$ \\
\hline & 2) Fen & 109 & 228,28 & & & & $3>2(r=-0.12)$ \\
\hline & 3) Meslek & 186 & 269,88 & & & & \\
\hline \multirow[t]{3}{*}{ M-17 Kavga etme } & 1) Ana. L. & 237 & 264,83 & 2 & 72,820 &, $000 *$ & $1>2(r=-0.32)$ \\
\hline & 2) Fen & 109 & 171,83 & & & & $3>1(r=-0.21)$ \\
\hline & 3) Meslek & 186 & 324,10 & & & & $3>2(r=-0.46)$ \\
\hline \multirow{3}{*}{$\begin{array}{l}\text { M-18 Yaşça büyük ya da güçlü } \\
\text { öğrencilerin diğer öğrenciler } \\
\text { üzerinde baskı kurması }\end{array}$} & 1) Ana. L. & 237 & 260,06 & 2 & 15,781 &, $000 *$ & $3>1(r=-0.12)$ \\
\hline & 2) Fen & 109 & 227,52 & & & & $3>2(r=-0.22)$ \\
\hline & 3) Meslek & 186 & 297,54 & & & & \\
\hline \multirow{3}{*}{$\begin{array}{l}\text { M-19 Çeteleşerek öğrencileri tehdit } \\
\text { etme }\end{array}$} & 1) Ana. L. & 237 & 261,70 & 2 & 22,795 &, $000 *$ & $1>2(r=-0.14)$ \\
\hline & 2) Fen & 109 & 218,32 & & & & $3>1(r=-0.13)$ \\
\hline & 3) Meslek & 186 & 300,84 & & & & $3>2(r=-0.27)$ \\
\hline \multirow[t]{3}{*}{ M-20 Öğretmenlerle dalga geçme } & 1) Ana. L. & 237 & 267,13 & 2 & 9,384 &, $009 *$ & $1>2(r=-0.11)$ \\
\hline & 2) Fen & 109 & 231,62 & & & & $3>2(r=-0.18)$ \\
\hline & 3) Meslek & 186 & 286,14 & & & & \\
\hline \multirow[t]{3}{*}{ M-21 Öğretmenlere lakap takma } & 1) Ana. L. & 237 & 265,16 & 2 & 9,280 &, $010^{*}$ & $3>2(r=-0.18)$ \\
\hline & 2) Fen & 109 & 233,25 & & & & \\
\hline & 3) Meslek & 186 & 287,70 & & & & \\
\hline \multirow[t]{3}{*}{ M-22 Öğrencilerle dalga geçme } & 1) Ana. L. & 237 & 276,98 & 2 & 13,567 &, $001 *$ & $1>2(r=-0.18)$ \\
\hline & 2) Fen & 109 & 219,36 & & & & $3>2(r=-0.19)$ \\
\hline & 3) Meslek & 186 & 280,77 & & & & \\
\hline \multirow[t]{3}{*}{ M-23 Öğrencilere lakap takma } & 1) Ana. L. & 237 & 276,14 & 2 & 17,127 &, $000 *$ & $1>2(r=-0.20)$ \\
\hline & 2) Fen & 109 & 213,89 & & & & $3>2(r=-0.22)$ \\
\hline & 3) Meslek & 186 & 285,04 & & & & \\
\hline \multirow[t]{2}{*}{ M-24 Yalan söylemek } & 1) Ana. L. & 237 & 276,42 & 2 & 7,520 &, $023 *$ & $1>2(r=-0.14)$ \\
\hline & 2) Fen & 109 & 231,39 & & & & $3>2(r=-0.13)$ \\
\hline
\end{tabular}




\begin{tabular}{|c|c|c|c|c|c|c|c|}
\hline \multirow{4}{*}{$\begin{array}{l}\text { M-25 Koridor ve merdivenlerde } \\
\text { birbirini itme, gürültü ve kargaşa } \\
\text { yaşanması }\end{array}$} & 3) Meslek & 186 & 274,44 & & & & \\
\hline & 1) Ana. L. & 237 & 277,84 & \multirow[t]{3}{*}{2} & \multirow[t]{3}{*}{21,770} & \multirow[t]{3}{*}{,000* } & $1>2(r=-0.22)$ \\
\hline & 2) Fen & 109 & 207,22 & & & & $3>2(r=-0.25)$ \\
\hline & 3) Meslek & 186 & 286,79 & & & & \\
\hline \multirow{3}{*}{$\begin{array}{l}\text { M-26 Okulla ilgisiz kişilerin okul } \\
\text { içerisinde ve çevresinde öğrencileri } \\
\text { rahatsız etmesi }\end{array}$} & 1) Ana. L. & 237 & 239,24 & \multirow[t]{3}{*}{2} & \multirow[t]{3}{*}{87,316} & \multirow[t]{3}{*}{,000* } & $1>2(r=-0.15)$ \\
\hline & 2) Fen & 109 & 194,63 & & & & $3>1(\mathrm{r}=-0.35)$ \\
\hline & 3) Meslek & 186 & 343,35 & & & & $3>2(r=-0.50)$ \\
\hline \multirow{3}{*}{$\begin{array}{l}\text { M-27 Başkasının malına zarar } \\
\text { vermek }\end{array}$} & 1) Ana. L. & 237 & 272,20 & \multirow[t]{3}{*}{2} & \multirow[t]{3}{*}{28,849} & \multirow[t]{3}{*}{, $000 *$} & $1>2(r=-0.22)$ \\
\hline & 2) Fen & 109 & 202,62 & & & & $3>2(r=-0.31)$ \\
\hline & 3) Meslek & 186 & 296,67 & & & & \\
\hline \multirow{3}{*}{$\begin{array}{l}\text { M-28 Başkasının malını haberi } \\
\text { olmadan almayı alışkanlık hâline } \\
\text { getirmek. }\end{array}$} & 1) Ana. L. & 237 & 272,28 & \multirow[t]{3}{*}{2} & \multirow[t]{3}{*}{14,415} & \multirow[t]{3}{*}{, $001 *$} & $1>2(r=-0.17)$ \\
\hline & 2) Fen & 109 & 220,77 & & & & $3>2(r=-0.21)$ \\
\hline & 3) Meslek & 186 & 285,94 & & & & \\
\hline
\end{tabular}

$$
* \mathrm{p}<.05
$$

Bulgular lise türüne göre incelendiğinde araştırmaya katılan öğrencilerin görüşlerinin 6 . Madde dışındaki bütün maddelerde anlamlı düzeyde farklılıklar gösterdiği anlaşılmaktadır. Öğrencilerin lise türüne göre disiplin problemlerinin yaşanma sıklığına ilişkin görüşleri arasında istatistiksel açıdan anlamlı farklılaşmalara rastlanmıştır. Sıra ortalamaları dikkate alındığında, $M$ $1 M-2$ M-4 M-7, M-9, M-10, M-11, M-12, M-13, M-14, M-15, M-17, M-18, M-19, M-20, M-21, $M-22, M-23, M-25, M-26, M-27, M-28$ maddelerinde Mesleki ve Teknik Liselerdeki öğrencilerin en yüksek puanı aldıkları görülmektedir. Bu da öğrenci görüşlerine göre Mesleki ve Teknik Liselerde yukarıda belirtilen disiplin problemlerinin daha sık yaşandığ 1 şeklinde yorumlanabilir. $M-3, M-5, M-8, M-16, M-24$ maddelerinde ise Anadolu Liselerindeki öğrencilerin en yüksek puanı aldıkları görülmektedir.

İkili karşılaştırmalarda istatistiksel olarak anlamlı bulunan bu farklar için hesaplanan etki değerlerine bakıldığında $M$-26 Okulla ilgisiz kişilerin okul içerisinde ve çevresinde öğrencileri rahatsız etmesi ( $r=-0.50)$, davranışının yüksek düzeyde; $M-2$ Ögrencilerin yanlarında kesici ve delici aletler bulundurması ( $r=-0.30), M-4$ Okuldan kaçma ( $r=-0.34), M-13$ Öğretmenlere karşı saygısız davranışlarda bulunma ( $r=-0.30)$, M-17 Kavga etme ( $r=-0.46)$ ve M-27 Başkasının malına zarar vermek $(r=-0.31)$ davranışlarının ise orta düzeyde etki değeri $(\mathrm{r}>.3)$ olduğu ve bu davranışın yaşanma sıklığına ilişkin öğrenci görüşlerinin pratikte manidar olduğu görülmektedir. Buna göre belirtilen davranışların Mesleki ve Teknik Liselerde Fen Liselerine oranla daha yaygın olduğu söylenebilir.

Diğer yandan $M-2, M-13, M-14, M-17, M-18, M-19, M-26$ maddelerinde belirtilen davranışların ise Mesleki ve teknik liselerde Anadolu Liselerine oranla daha sık görüldüğü, $M-3$ Cep telefonu ve kamerayı kötü amaçlı kullanma maddesinde belirtilen davranışın ise Meslek Liselerine oranla Anadolu Liselerinde daha sık görüldüğ̈̈ anlaşılmaktadır.

İkili karşılaştırmalarda istatistiksel olarak anlamlı bulunan bu farklar için hesaplanan etki değerlerine bakıldığında $M$-26 Okulla ilgisiz kişilerin okul içerisinde ve çevresinde ögrencileri rahatsız etmesi $(r=-0.35)$ davranışının orta düzeyde etki değeri olduğu ve bu davranışın yaşanma sıklığına ilişkin öğrenci görüşlerinin pratikte manidar olduğu görülmektedir. Buna göre Fen liseleriyle kıyaslandığında, Mesleki ve Teknik Liselerde okulla ilgisiz kişilerin okul içerisinde ve çevresinde öğrencileri rahatsız etmesi durumuyla daha sık karşılaşıldığı anlaşılmaktadır.

\section{Okullarda yaşanan disiplin problemlerinin nedenlerine ilişkin bulgular}

Öğretmen ve öğrencilerin disiplin problemlerinin nedenlerine ilişkin görüşlerinin dağılımını belirlemek amacıyla ölçek ve her bir alt boyut için, elde edilen veriler üzerinden betimsel istatistik hesaplamaları yapılmıştır. Bu bağlamda, katılımcı görüşlerinin ölçeğin tamamı ve alt boyutlarında almış oldukları en düşük puanlar, en yüksek puanlar, aritmetik ortalama ve standart sapma değerleri hesaplanmıştır. Tablo 9'daki bulgular incelendiğinde okullarda yaşanan disiplin 
problemlerinin nedenlerine ilişkin öğretmen görüşlerinin ölçeğin aileden ve başarısızlıktan kaynaklanan nedenler boyutlarında Çoğunlukla etkilidir düzeyinde, diğer boyutlar toplamda ise Orta Düzeyde Etkilidir düzeyinde yoğunlaştığı görülmektedir.

Disiplin problemlerinin nedenlerine ilişkin öğrenci görüşlerinin ölçeğin bütün boyutlarında ve toplamda Orta Düzeyde Etkilidir düzeyinde yoğunlaştı̆̆ görülmektedir.

Tablo 9.

Okullarda Yaşanan Disiplin Sorunlarının Nedenleri Ölçeğinden Öğretmen ve Öğrencilerin Aldıkları Puanlara İlișkin Betimsel İstatistik Sonuçları

\begin{tabular}{|c|c|c|c|c|c|c|c|c|c|c|c|c|}
\hline \multicolumn{7}{|c|}{ Öğretmen Ölçeği } & \multicolumn{6}{|c|}{ Öğrenci Ölçeği } \\
\hline Düzey & $\mathrm{N}$ & $\mathrm{X}$ & SS & $\begin{array}{c}\text { En } \\
\text { düşük }\end{array}$ & $\begin{array}{l}\text { En } \\
\text { Yüksek }\end{array}$ & Boyut & $\begin{array}{c}\text { En } \\
\text { düşük }\end{array}$ & $\begin{array}{c}\text { En } \\
\text { Yüksek }\end{array}$ & $\mathrm{N}$ & $\mathrm{X}$ & SS & Düzey \\
\hline $\begin{array}{c}\text { Orta } \\
\text { düzeyde } \\
\text { etkilidir }\end{array}$ & 691 & 24,78 & 8,41 & 8 & 40 & $\begin{array}{l}\text { Öğretmenden } \\
\text { Kaynaklanan } \\
\text { Nedenler }\end{array}$ & 8 & 40 & 1001 & 21,77 & 7,50 & $\begin{array}{c}\text { Orta } \\
\text { düzeyde } \\
\text { etkilidir }\end{array}$ \\
\hline $\begin{array}{c}\text { Orta } \\
\text { düzeyde } \\
\text { etkilidir }\end{array}$ & 691 & 16,77 & 5,31 & 5 & 25 & $\begin{array}{c}\text { Yönetimden } \\
\text { Kaynaklanan } \\
\text { Nedenler }\end{array}$ & 5 & 25 & 1001 & 13,72 & 5,58 & $\begin{array}{c}\text { Orta } \\
\text { düzeyde } \\
\text { etkilidir }\end{array}$ \\
\hline $\begin{array}{l}\text { Çoğunlukl } \\
\text { a etkilidir }\end{array}$ & 691 & 14,80 & 3,70 & 4 & 20 & $\begin{array}{c}\text { Aileden } \\
\text { Kaynaklanan } \\
\text { Nedenler }\end{array}$ & 4 & 20 & 1001 & 10,76 & 4,67 & $\begin{array}{c}\text { Orta } \\
\text { düzeyde } \\
\text { etkilidir }\end{array}$ \\
\hline $\begin{array}{c}\text { Orta } \\
\text { düzeyde } \\
\text { etkilidir }\end{array}$ & 691 & 15,79 & 4,52 & 5 & 25 & $\begin{array}{l}\text { Okul Kaynaklı } \\
\text { Nedenler }\end{array}$ & 5 & 25 & 1001 & 16,67 & 5,20 & $\begin{array}{c}\text { Orta } \\
\text { düzeyde } \\
\text { etkilidir }\end{array}$ \\
\hline $\begin{array}{l}\text { Çoğunlukl } \\
\text { a etkilidir }\end{array}$ & 691 & 10,95 & 2,98 & 3 & 15 & $\begin{array}{c}\text { Başarısızlıktan } \\
\text { Kaynaklanan } \\
\text { Nedenler }\end{array}$ & 3 & 15 & 1001 & 8.86 & 3,53 & $\begin{array}{c}\text { Orta } \\
\text { düzeyde } \\
\text { etkilidir }\end{array}$ \\
\hline $\begin{array}{c}\text { Orta } \\
\text { düzeyde } \\
\text { etkilidir }\end{array}$ & 691 & 13.68 & 3,30 & 4 & 20 & $\begin{array}{l}\text { Öğrenciden } \\
\text { Kaynaklanan } \\
\text { Nedenler }\end{array}$ & 4 & 20 & 1001 & 12,93 & 4,26 & $\begin{array}{c}\text { Orta } \\
\text { düzeyde } \\
\text { etkilidir }\end{array}$ \\
\hline $\begin{array}{c}\text { Orta } \\
\text { düzeyde } \\
\text { etkilidir }\end{array}$ & 691 & 96,76 & 22,39 & 29 & 145 & Toplam & 29 & 145 & 1001 & 85,44 & $\begin{array}{c}31,4 \\
1\end{array}$ & $\begin{array}{c}\text { Orta } \\
\text { düzeyde } \\
\text { etkilidir }\end{array}$ \\
\hline
\end{tabular}

Tablo 10'da disiplin problemlerinin nedenlerine ilişkin öğretmen ve öğrenci görüşleri arasındaki farklılaşmaya ilişkin $\mathrm{t}$ testi sonuçları sunulmaktadır.

$\mathrm{Bu}$ bulgular, öğretmenden kaynaklanan nedenler boyutu açısından incelendiğinde, öğretmenlerin $(X=24,77)$, öğrencilere $(X=21,76)$ göre daha yüksek aritmetik ortalamalara sahip oldukları görülmektedir. Bu bulguya göre, öğretmenler öğrencilerle karşılaştırıldığında disiplin sorunlarının daha çok öğretmen kaynaklı olduğunu düşünmektedir. Etki büyüklüğüne ilişkin hesaplanan $\eta 2$ değeri (.10), ve Cohen d değeri (.37) göz önünde bulundurulduğunda, öğretmenden kaynaklı nedenler açısından statü(öğretmen-öğrenci) değişkeninin "orta" etki büyüklügüne sahip olduğu ve elde edilen bulgunun pratikte manidar olduğu söylenebilir.

Yönetimden kaynaklanan nedenler boyutu açısından bakıldığında, öğretmenlerin $(X=16,77)$, öğrencilere $(X=13,71)$ göre daha yüksek aritmetik ortalamalara sahip oldukları görülmektedir. $\mathrm{Bu}$ bulguya göre, öğretmenler öğrencilerle karşılaştırıldığında disiplin sorunlarının daha çok okul yönetiminden kaynaklı olduğunu düşünmektedir. Statü (öğretmenöğrenci) ile yönetimden kaynaklanan nedenler arasında anlamlı bir ilişki olduğu görülmektedir. Etki büyüklügüne ilişkin hesaplanan $\eta 2$ değeri (.20) ve Cohen $\mathrm{d}$ değeri (.56) göz önünde bulundurulduğunda, yönetimden kaynaklı nedenler açısından statü (öğretmen-öğrenci) değişkeninin "büyük" etki büyüklüğüne sahip olduğu ve elde edilen bulgunun pratikte manidar olduğu söylenebilir. 
Tablo 10.

Disiplin problemlerinin nedenlerine dair öğretmen ve öğrenci görüşleri arasındaki farklılaşmaya ilişkin t testi sonuçları

\begin{tabular}{|c|c|c|c|c|c|c|c|c|c|}
\hline Boyut & Statü & $\mathrm{N}$ & $X$ & SS & $\mathrm{T}$ & $\mathrm{Sd}$ & $\mathrm{p}$ & $\eta 2$ & $\begin{array}{c}\text { Cohen } \\
\mathrm{d}\end{array}$ \\
\hline \multirow{2}{*}{$\begin{array}{c}\text { Öğretmenden } \\
\text { Kaynaklanan } \\
\text { Nedenler }\end{array}$} & Öğretmen & 691 & 24,77 & 1,051 & 7,550 & 1370,58 & ,000 & ,10 &, 37 \\
\hline & Öğrenci & 1001 & 21,76 & ,938 & & & & & \\
\hline \multirow{2}{*}{$\begin{array}{l}\text { Yönetimden } \\
\text { Kaynaklanan } \\
\text { Nedenler }\end{array}$} & Öğretmen & 691 & 16,77 & 1,062 & 11,391 & 1528,59 & , 000 & ,20 &, 56 \\
\hline & Öğrenci & 1001 & 13,71 & 1,115 & & & & & \\
\hline \multirow{2}{*}{$\begin{array}{c}\text { Aileden } \\
\text { Kaynaklanan } \\
\text { Nedenler }\end{array}$} & Öğretmen & 691 & 14,80 & ,926 & 19,783 & 1657,65 & ,000 & ,42 & ,98 \\
\hline & Öğrenci & 1001 & 10,76 & 1,167 & & & & & \\
\hline \multirow{2}{*}{$\begin{array}{c}\text { Okul } \\
\text { Kaynaklı } \\
\text { Nedenler }\end{array}$} & Öğretmen & 691 & 15,78 & ,903 & $-3,724$ & 1603,96 & ,000 &, 03 &,- 18 \\
\hline & Öğrenci & 1001 & 16,67 & 1,040 & & & & & \\
\hline \multirow{4}{*}{$\begin{array}{c}\text { Başarısızlıkta } \\
\text { n } \\
\text { Kaynaklanan } \\
\text { Nedenler } \\
\text { Öğrenciden } \\
\text { Kaynaklanan } \\
\text { Nedenler }\end{array}$} & Öğretmen & 691 & 10,94 & ,992 & 13,106 & 1623,13 & ,000 &, 24 & ,65 \\
\hline & Öğrenci & 1001 & 8,86 & 1,175 & & & & & \\
\hline & Öğretmen & 691 & 13,68 &, 825 & 4,102 & 1666,56 & ,000 & ,03 &, 20 \\
\hline & Öğrenci & 1001 & 12,92 & 1,062 & & & & & \\
\hline \multirow[t]{2}{*}{ TOPLAM } & Öğretmen & 691 & 96,76 & ,772 & 10,622 & 1690 & ,000 & ,17 & ,53 \\
\hline & Öğrenci & 1001 & 84,71 & ,803 & & & & & \\
\hline
\end{tabular}

$\mathrm{p}<.05$

Aileden Kaynaklanan Nedenler boyutu açısından bakıldığında, öğretmenlerin $(X=14,80)$, öğrencilere $(X=10,76)$ göre daha yüksek aritmetik ortalamalara sahip oldukları görülmektedir. $\mathrm{Bu}$ bulguya göre, öğretmenler öğrencilerle karşılaştırıldığında disiplin sorunlarının aileden kaynaklı olduğunu düşünmektedir. Statü (öğretmen-öğrenci) ile aileden kaynaklanan nedenler arasında anlamlı bir ilişki olduğu görülmektedir. Etki büyüklüğüne ilişkin hesaplanan $\eta 2$ değeri (.42) ve Cohen d değeri (.98) göz önünde bulundurulduğunda, aileden kaynaklanan nedenler açısından statü(öğretmen-öğrenci) değişkeninin büyük” etki büyüklüğüne sahip olduğu ve elde edilen bulgunun pratikte manidar olduğu söylenebilir.

Okuldan Kaynaklı Nedenler boyutu açısından bakıldığında, öğrencilerin $(X=16,67)$ ögrretmenlere $(X=15,78)$ göre daha yüksek aritmetik ortalamalara sahip oldukları görülmektedir. Bu bulguya göre, öğrenciler öğretmenlere karşılaştırıldığında disiplin sorunlarının daha çok okul kaynaklı olduğunu düşünmektedir. Statü (öğretmen-öğrenci) ile okul kaynaklı nedenler arasında anlamlı bir ilişki olduğu görülmektedir. Etki büyüklüğüne ilişkin hesaplanan $\eta 2$ değeri $(, 03)$ ve Cohen d değeri (-,18) göz önünde bulundurulduğunda, okuldan kaynaklı nedenler açısından statü (öğretmen-öğrenci) değişkeninin "düşük" etki büyüklüğüne sahip olduğu ve dolayısıyla elde edilen bulgunun pratikte sorgulanabilir olduğu söylenebilir.

Başarısızlıktan Kaynaklanan Nedenler boyutu açısından bakıldığında, görev yapan öğretmenlerin $(X=10,9465)$, öğrencilere $(X=8,8641)$ göre daha yüksek aritmetik ortalamalara sahip oldukları görülmektedir. Bu bulguya göre, öğretmenler öğrencilerle karşılaştırıldığında disiplin sorunlarının başarısızlıktan kaynaklı olduğunu düşünmektedir. Statü (öğretmen-öğrenci) ile başarısızlıktan kaynaklanan nedenler arasında anlamlı bir ilişki olduğu görülmektedir. Etki büyüklüğüne ilişkin hesaplanan $\eta 2$ değeri (.24), ve Cohen $\mathrm{d}$ değeri (.65) göz önünde bulundurulduğunda, başarısızlık kaynaklı nedenler açısından statü(öğretmen-öğrenci) değişkeninin "büyük" etki büyüklüğüne sahip olduğu ve elde edilen bulgunun pratikte manidar olduğu söylenebilir. 
Öğrenciden kaynaklanan nedenler boyutu açısından bakıldığında, öğretmenlerin $(X=13,68)$, öğrencilere $(X=12,92)$ göre daha yüksek aritmetik ortalamalara sahip oldukları görülmektedir. $\mathrm{Bu}$ bulguya göre, öğretmenler öğrencilerle karşılaştırıldığında disiplin sorunlarının öğrenci kaynaklı olduğunu düşünmektedir. Statü (öğretmen-öğrenci) ile öğrenciden kaynaklanan nedenler arasında anlamlı bir ilişki olduğu görülmektedir. Etki büyüklügüne ilişkin hesaplanan $\eta 2$ değeri (.03) ve Cohen d değeri (.20) göz önünde bulundurulduğunda, öğrenciden kaynaklanan nedenler açısından statü(öğretmen-öğrenci) değişkeninin "orta" etki büyüklüğüne sahip olduğu ve elde edilen bulgunun pratikte manidar olduğu söylenebilir.

\section{Cinsiyet değişkenine göre öğretmenlerin disiplin problemlerine iliş̧in görüşleri}

Tablo 11'de disiplin problemlerinin nedenlerinin cinsiyet değişkenine göre öğretmen görüşleri arasındaki farklılaşmaya ilişkin $t$ testi sonuçları sunulmaktadır. Öğretmenden, yönetimden, okul kaynaklı nedenler boyutları açısından bakıldığında, araştırmaya katılan öğretmenlerin algıları arasında cinsiyet açısından anlamlı farklılık olmadığı görülmektedir.

Tablo 11.

Disiplin problemlerinin nedenlerine ilişkin cinsiyet değişkenine göre öğretmen görüşleri arasındaki farklılaşmaya iliş̧in $\mathrm{t}$ testi sonuçları

\begin{tabular}{|c|c|c|c|c|c|c|c|c|c|}
\hline Boyut & Cinsiyet & $\mathrm{N}$ & $\mathrm{X}$ & SS & $\mathrm{T}$ & $\mathrm{Sd}$ & $\mathrm{p}$ & $\eta 2$ & $\begin{array}{c}\text { Cohen } \\
\mathrm{d}\end{array}$ \\
\hline \multirow{2}{*}{$\begin{array}{l}\text { Öğretmenden } \\
\text { Kaynaklanan } \\
\text { Nedenler }\end{array}$} & Kadın & 349 & 25,13 & 1,106 & 1,121 & 683,65 & ,263 & & \\
\hline & Erkek & 342 & 24,41 & ,992 & & & & & \\
\hline \multirow{3}{*}{$\begin{array}{l}\text { Yönetimden } \\
\text { Kaynaklanan } \\
\text { Nedenler } \\
\text { Aileden }\end{array}$} & Kadın & 349 & 17,03 & 1,126 & 1,310 & 681,27 & 191 & & \\
\hline & Erkek & 342 & 16.5 & ,991 & & & & & \\
\hline & Kadın & 349 & 15,22 & 932 & 3,062 & 689 & ,002 & .02 & .23 \\
\hline $\begin{array}{l}\text { Kaynaklanan } \\
\text { Nedenler }\end{array}$ & Erkek & 342 & 14.36 & 908 & & & & & \\
\hline \multirow{2}{*}{$\begin{array}{l}\text { Okul Kaynaklı } \\
\text { Nedenler }\end{array}$} & Kadın & 349 & 16.01 & ,942 & 1,318 & 689 & , 188 & & \\
\hline & Erkek & 342 & 15.55 & 861 & & & & & \\
\hline \multirow{4}{*}{$\begin{array}{c}\text { Başarısızlıktan } \\
\text { Kaynaklanan } \\
\text { Nedenler } \\
\text { Öğrenciden } \\
\text { Kaynaklanan } \\
\text { Nedenler }\end{array}$} & Kadın & 349 & 11.27 & ,983 & 2,948 & 689 & ,003 & .02 & .22 \\
\hline & Erkek & 342 & 10.61 & 989 & & & & & \\
\hline & Kadın & 349 & 13.96 & ,844 & 2,313 & 689 & ,021 & .01 & .18 \\
\hline & Erkek & 342 & 13,38 & ,801 & & & & & \\
\hline \multirow[t]{2}{*}{ TOPLAM } & Kadın & 349 & 98.64 & ,808 & 2,237 & 689 & ,026 & .01 & .17 \\
\hline & Erkek & 342 & 94,84 &, 728 & & & & & \\
\hline
\end{tabular}

Aileden kaynaklanan nedenler boyutu açısından bakıldığında, araştırmaya katılan kadın öğretmenlerin ( $X=15,22)$, erkek öğretmenlere $(X=14.36)$ göre daha yüksek aritmetik ortalamalara sahip oldukları görülmektedir. Bu bulguya göre, kadın öğretmenler erkek öğretmenlerle karşılaştırıldığında disiplin sorunlarının daha çok aileden kaynaklı olduğunu düşünmektedir. Cinsiyet ile aileden kaynaklanan nedenler arasında anlamlı bir ilişki olduğu görülmektedir. Etki büyüklüğüne ilişkin hesaplanan $\eta 2$ değeri (.02) ve Cohen $\mathrm{d}$ değeri (.23) göz önünde bulundurulduğunda, aile kaynaklı nedenler açısından cinsiyet değişkeninin "orta" etki büyüklüğüne sahip olduğu ve elde edilen bulgunun pratikte manidar olduğu söylenebilir.

Başarısızlıktan kaynaklanan nedenler boyutu açısından bakıldığında, araştırmaya katılan kadın öğretmenlerin $(X=11.2752)$, erkek öğretmenlere $(X=10.611)$ göre daha yüksek aritmetik ortalamalara sahip oldukları görülmektedir. $\mathrm{Bu}$ bulguya göre, kadın öğretmenler erkek öğretmenlerle karşılaştırıldığında disiplin sorunlarının öğrenci başarısızlığından kaynaklandığını 
düşünmektedir. Cinsiyet ile başarısızlıktan kaynaklanan nedenler arasında anlamlı bir ilişki olduğu görülmektedir. Etki büyüklüğüne ilişkin hesaplanan $\eta 2$ değeri (.02), ve Cohen $\mathrm{d}$ değeri (.22) göz önünde bulundurulduğunda, başarısızlık kaynaklı nedenler açısından cinsiyet değişkeninin "orta" etki büyüklüğüne sahip olduğu ve elde edilen bulgunun pratikte manidar olduğu söylenebilir.

Öğrenciden Kaynaklanan Nedenler boyutu açısından bakıldığında, araştırmaya katılan kadın öğretmenlerin $(X=13.96)$, erkek öğretmenlere $(X=13,38)$ göre daha yüksek aritmetik ortalamalara sahip oldukları görülmektedir. $\mathrm{Bu}$ bulguya göre, kadın öğretmenler erkek öğretmenlerle karşılaştırıldığında disiplin sorunlarının daha çok öğrenciden kaynaklı olduğunu düşünmektedir. Cinsiyet ile öğrenciden kaynaklanan nedenler arasında anlamlı bir ilişki olduğu görülmektedir. Etki büyüklüğüne ilişkin hesaplanan $\eta 2$ değeri (.01), ve Cohen d değeri (.18) göz önünde bulundurulduğunda, öğrenciden kaynaklanan nedenler açısından cinsiyet değişkeninin "küçük" etki büyüklügüne sahip olduğu ve elde edilen bulgunun pratikte sorgulanabilir olduğu söylenebilir.

\section{Mesleki kıdem değişkenine göre öğretmenlerin disiplin problemlerine ilişkin görüşleri}

Öğretmenlerin okullarda yaşanan disiplin problemlerinin nedenlerine ilişkin algılarının mesleki kıdem değişkenine göre değişip değişmediğini test etmek amacıyla yapılan ANOVA testi sonucu Tablo 12'de yer almaktadır.

Tablo 12'de görüldüğü gibi, öğretmenlerin okullarda yaşanan disiplin problemlerinin nedenlerine ilişkin algılarının kıdem değişkenine göre ölçeğin boyutlarında anlamlı biçimde farklılaşmadığı görülmüştür.

Tablo 12.

Meslekteki kıdem değişkenine göre öğretmenlerin disiplin problemlerine ilişkin görüşleri

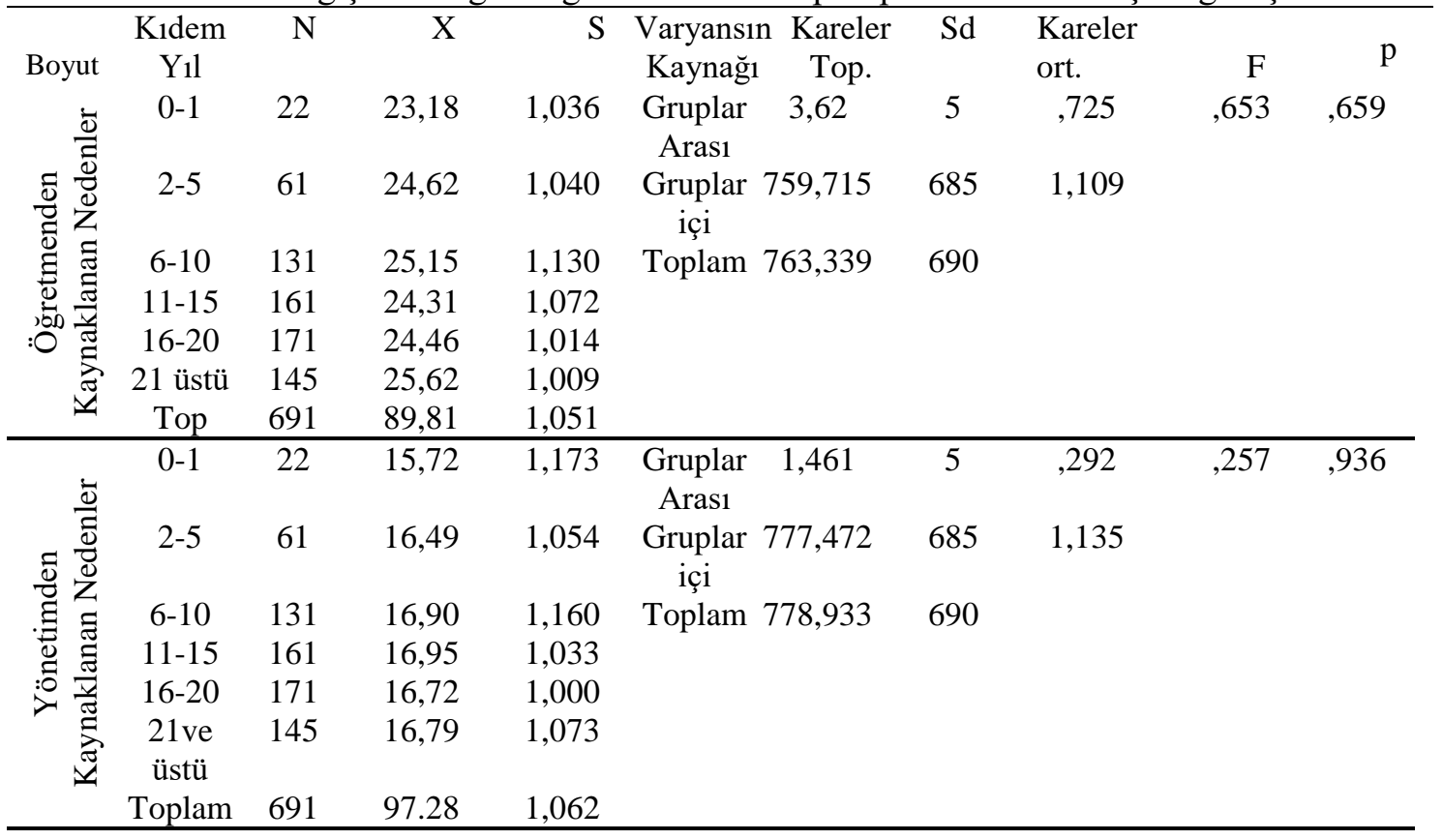

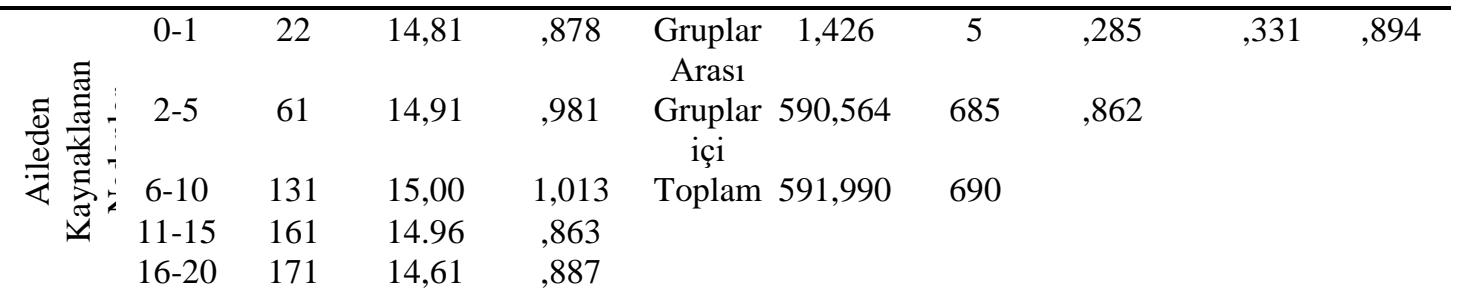




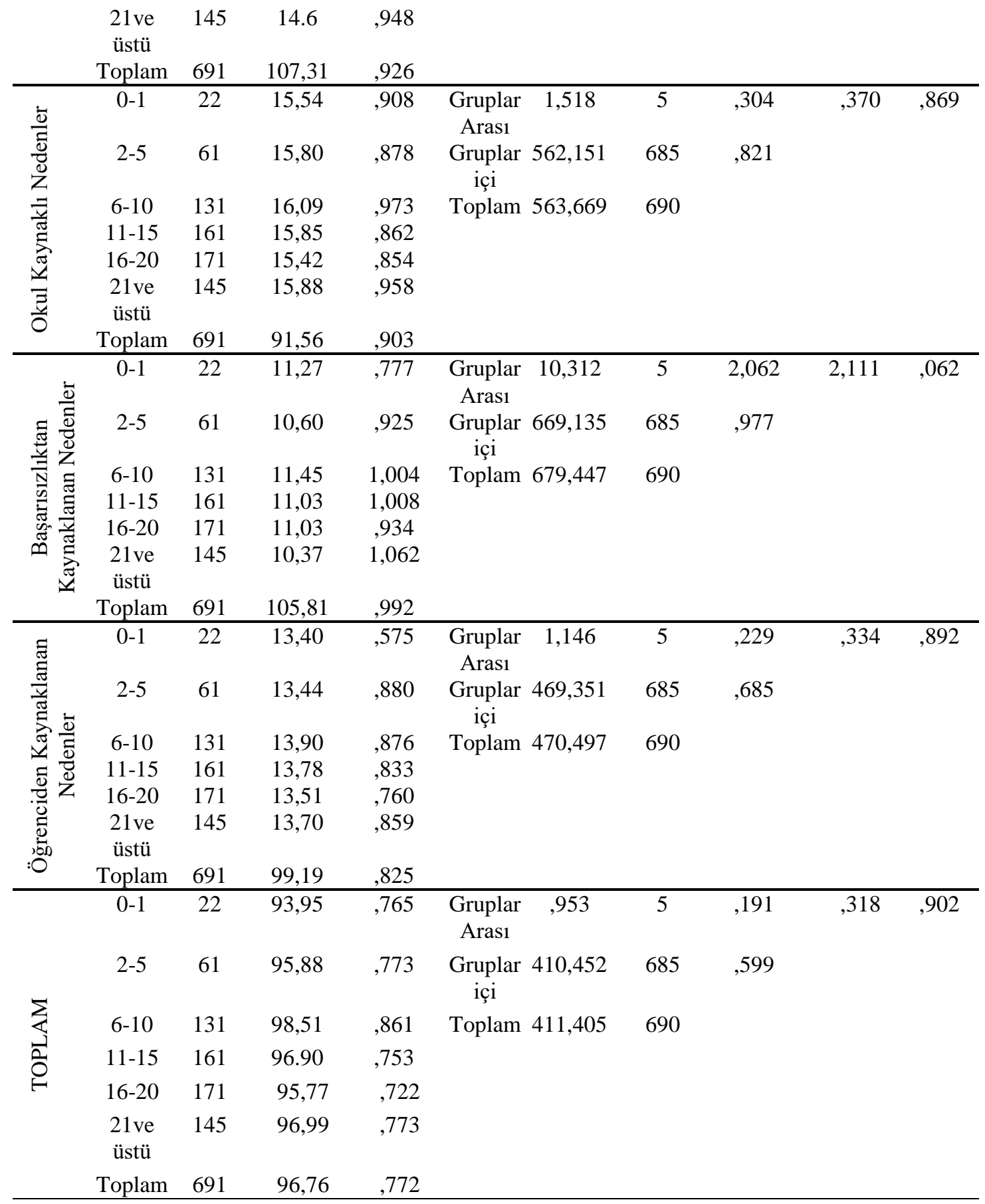

\section{Cinsiyet değișkenine göre öğrencilerin disiplin problemlerine ilișkin görüșleri}

Tablo 13'te disiplin problemlerinin nedenleriyle ilgili olarak cinsiyet değişkenine göre öğrenci görüşleri arasındaki farklılaşmaya ilişkin $\mathrm{t}$ testi sonuçları sunulmaktadır. Bu bulguya göre öğrencilerin cinsiyeti ile Yönetimden kaynaklanan nedenler dışındaki diğer boyutlar arasında anlamlı bir farklılaşma yoktur.

Yönetimden Kaynaklanan Nedenler boyutu açısından bakıldığında, araştırmaya katılan erkek öğrenciler $(X=14,06)$ kız öğrencilere $(X=13,37)$ göre daha yüksek aritmetik ortalamalara sahip oldukları görülmektedir. $\mathrm{Bu}$ bulguya göre, erkek öğrenciler kı öğrencilerle karşılaştırıldığında disiplin sorunlarının daha çok yönetimden kaynaklı olduğunu düşünmektedir. Cinsiyet ile yönetimden kaynaklanan nedenler boyutu arasında anlamlı bir ilişki olduğu görülmektedir. Etki büyüklügüne ilişkin hesaplanan $\eta 2$ değeri (.01), ve Cohen d değeri (.12)göz 
önünde bulundurulduğunda, yönetimden kaynaklanan nedenler boyutu açısından cinsiyet değişkeninin "küçük" etki büyüklüğüne sahip olduğu, dolayısıyla pratik açıdan manidarlığın sorgulanabilir olduğu söylenebilir.

Tablo 13

Disiplin problemlerinin nedenleriyle ilgili olarak cinsiyet değişkenine göre öğrenci görüşleri arasındaki farklılaşmaya ilişkin $\mathrm{t}$ testi sonuçları

\begin{tabular}{|c|c|c|c|c|c|c|c|c|c|}
\hline Boyut & Cinsiyet & $\mathrm{N}$ & $\mathrm{X}$ & SS & $\mathrm{T}$ & $\mathrm{Sd}$ & $\mathrm{p}$ & \multirow[t]{2}{*}{$\eta 2$} & Cohen d \\
\hline \multirow{2}{*}{$\begin{array}{l}\text { Öğretmenden } \\
\text { Kaynaklanan }\end{array}$} & $\mathrm{K} 1 \mathrm{Z}$ & 504 & 21,37 & ,996 & $-1,677$ & 985,15 & ,094 & & \\
\hline & & & & & & & & & \\
\hline Nedenler & Erkek & 497 & 22,16 & ,872 & & & & & \\
\hline Yönetimden & $\mathrm{K} 1 \mathrm{z}$ & 504 & 13,37 & 1,162 & $-1,977$ & 993,17 &, 048 & 0 & ,012 \\
\hline $\begin{array}{l}\text { Kaynaklanan } \\
\text { Nedenler }\end{array}$ & Erkek & 497 & 14,06 & 1,061 & & & & 1 & \\
\hline Aileden & $\mathrm{K} 1 \mathrm{z}$ & 504 & 10,82 & 1,228 & ,417 & 990,41 & ,676 & & \\
\hline $\begin{array}{l}\text { Kaynaklanan } \\
\text { Nedenler }\end{array}$ & Erkek & 497 & 10,70 & 1,103 & & & & & \\
\hline Okul Kaynaklı & $\mathrm{K} 1 \mathrm{z}$ & 504 & 16,71 & 1,082 &, 251 & 994,53 &, 802 & & \\
\hline & Erkek & 497 & 16,63 & ,997 & & & & & \\
\hline Başarısızlıktan & $\mathrm{K} 1 \mathrm{z}$ & 504 & 8,91 & 1,248 & ,493 & 986,18 & ,622 & & \\
\hline $\begin{array}{l}\text { Kaynaklanan } \\
\text { Nedenler }\end{array}$ & Erkek & 497 & 8,80 & 1,097 & & & & & \\
\hline Öğrenciden & Kiz & 504 & 13,03 & 1,100 & ,844 & 995,46 & ,399 & & \\
\hline $\begin{array}{l}\text { Kaynaklanan } \\
\text { Nedenler }\end{array}$ & Erkek & 497 & 12,81 & 1,022 & & & & & \\
\hline TOPLAM & $\mathrm{K} 1 \mathrm{Z}$ & 504 & 84,24 & ,864 &,- 643 & 978,87 & 520 & & \\
\hline & Erkek & 497 & 85,19 & ,737 & & & & & \\
\hline
\end{tabular}

Eğitim Kademesi değişkenine göre öğrencilerin disiplin problemlerine ilişkin görüşleri

Tablo 14'de disiplin problemlerinin nedenleriyle ilgili olarak okul türü (ortaokul-lise) değişkenine göre öğrenci görüşleri arasındaki farklılaşmaya ilişkin $t$ testi sonuçları sunulmaktadır.

Öğretmenden Kaynaklanan Nedenler boyutu açısından bakıldığında, araştırmaya katılan lise öğrencileri $(X=22,9696)$ ortaokul öğrencilerine $(X=20,2936)$ göre daha yüksek aritmetik ortalamalara sahip oldukları görülmektedir. Bu bulguya göre, lise öğrenciler ortaokul öğrencileri ile karşılaştırıldığında disiplin sorunlarının öğretmenden kaynaklı olduğunu düşünmektedir. Okul türü ile öğretmenden kaynaklanan nedenler arasında anlamlı bir ilişki olduğu görülmektedir. Etki büyüklüğüne ilişkin hesaplanan $\eta 2$ değeri (.06), ve Cohen d değeri (-.36) göz önünde bulundurulduğunda, öğretmenden kaynaklı nedenler açısından eğitim kademesi değişkeninin "orta" etki büyüklüğüne sahip olduğu ve elde edilen bulgunun pratikte manidar olduğu söylenebilir.

Aileden kaynaklanan nedenler boyutu açısından bakıldığında, araştırmaya katılan lise öğrencileri $(X=11,1632)$ ortaokul öğrencilerine $(X=10,274)$ göre daha yüksek aritmetik ortalamalara sahip oldukları görülmektedir. Bu bulguya göre, lise öğrencileri ortaokul öğrencileri ile karşılaştırıldığında disiplin sorunlarının aileden kaynaklı olduğunu düşünmektedir. Okul türü ile aileden kaynaklanan nedenler arasında anlamlı bir ilişki olduğu görülmektedir. Etki büyüklüğüne ilişkin hesaplanan $\eta 2$ değeri (.02), ve Cohen d değeri $(-, 19)$ göz önünde bulundurulduğunda, aileden kaynaklanan nedenler açısından okul türü değişkeninin "küçük" etki büyüklüğüne sahip olduğu ve elde edilen bulgunun pratikte sorgulanabilir olduğu söylenebilir. 
Tablo 14.

Disiplin problemlerinin nedenleriyle ilgili olarak okul türü değişkenine göre öğrenci görüşleri arasındaki farklılaşmaya ilişkin $\mathrm{t}$ testi sonuçları

\begin{tabular}{|c|c|c|c|c|c|c|c|c|c|}
\hline Boyut & $\begin{array}{l}\text { Eğitim } \\
\text { Kademesi }\end{array}$ & $\mathrm{N}$ & $\mathrm{X}$ & SS & $\mathrm{T}$ & $\mathrm{Sd}$ & $\mathrm{p}$ & $\eta 2$ & $\begin{array}{c}\text { Cohen } \\
\text { d }\end{array}$ \\
\hline \multirow{2}{*}{$\begin{array}{l}\text { Öğretmenden } \\
\text { Kaynaklanan }\end{array}$} & Ortaokul & 449 & 20,29 & ,948 & $-5,697$ & 999 & ,000 & \multirow[t]{3}{*}{06} & \multirow[t]{5}{*}{,- 36} \\
\hline & & & & & & & & & \\
\hline Nedenler & Lise & 552 & 22,96 & ,903 & & & & & \\
\hline \multirow{2}{*}{$\begin{array}{c}\text { Yönetimden } \\
\text { Kaynaklanan } \\
\text { Nedenler }\end{array}$} & Ortaokul & 449 & 13,66 & 1,126 & \multirow[t]{2}{*}{,- 291} & \multirow[t]{2}{*}{999} & \multirow[t]{2}{*}{,771 } & & \\
\hline & Lise & 552 & 13,76 & 1,106 & & & & & \\
\hline \multirow{2}{*}{$\begin{array}{c}\text { Aileden } \\
\text { Kaynaklanan } \\
\text { Nedenler }\end{array}$} & Ortaokul & 449 & 10,27 & 1,177 & \multirow[t]{2}{*}{$-3,008$} & \multirow[t]{2}{*}{999} & \multirow[t]{2}{*}{,003 } & \multirow[t]{2}{*}{02} & \multirow[t]{2}{*}{,- 19} \\
\hline & Lise & 552 & 11,16 & 1,150 & & & & & \\
\hline \multirow{2}{*}{$\begin{array}{l}\text { Okul Kaynaklı } \\
\text { Nedenler }\end{array}$} & Ortaokul & 449 & 15,90 & 1,048 & \multirow[t]{2}{*}{$-4,241$} & \multirow[t]{2}{*}{999} & \multirow[t]{2}{*}{,000 } & \multirow[t]{2}{*}{03} & \multirow[t]{6}{*}{, 27} \\
\hline & Lise & 552 & 17,29 & 1,018 & & & & & \\
\hline \multirow{4}{*}{$\begin{array}{l}\text { Başarısızlıktan } \\
\text { Kaynaklanan } \\
\text { Nedenler } \\
\text { Öğrenciden } \\
\text { Kaynaklanan } \\
\text { Nedenler }\end{array}$} & Ortaokul & 449 & 8,72 & 1,172 & \multirow[t]{2}{*}{$-1,118$} & \multirow[t]{2}{*}{999} & \multirow[t]{2}{*}{,264 } & & \\
\hline & Lise & 552 & 8,97 & 1,176 & & & & & \\
\hline & Ortaokul & 449 & 13,06 & 1,098 & \multirow[t]{2}{*}{,953 } & \multirow[t]{2}{*}{999} & \multirow[t]{2}{*}{, 341} & & \\
\hline & Lise & 552 & 12.81 & 1,032 & & & & & \\
\hline \multirow[t]{2}{*}{ TOPLAM } & Ortaokul & 449 & 81,93 & 834 & \multirow[t]{2}{*}{$-3,400$} & \multirow[t]{2}{*}{922,95} & \multirow[t]{2}{*}{001} & \multirow[t]{2}{*}{,02 } & \multirow[t]{2}{*}{,- 22} \\
\hline & Lise & 552 & 86,98 & ,769 & & & & & \\
\hline
\end{tabular}

Okuldan kaynaklı nedenler boyutu açısından bakıldığında, araştırmaya katılan lise öğrencilerinin $(X=17,297)$ ortaokul öğrencilerine $(X=15,9065)$ göre daha yüksek aritmetik ortalamalara sahip oldukları görülmektedir. Bu bulguya göre, lise öğrencileri ortaokul öğrencileri ile karşılaştırıldığında disiplin sorunlarının okul kaynaklı olduğunu düşünmektedir. Okul türü ile okul kaynaklı nedenler arasında anlamlı bir ilişki olduğu görülmektedir. Etki büyüklüğüne ilişkin hesaplanan $\eta 2$ değeri (.03), ve Cohen $\mathrm{d}$ değeri (.27) göz önünde bulundurulduğunda, okuldan kaynaklı nedenler açısından eğitim kademesi değişkeninin "orta" etki büyüklüğüne sahip olduğu ve elde edilen bulgunun pratikte manidar olduğu söylenebilir.

Ölçeğin diğer boyutlarında öğrenci algıları arasında eğitim kademesi açısından anlamlı farklılık olmadığı görülmektedir.

\section{Sonuç ve Öneriler}

Bu çalışmada ortaokul ve liselerde yaşanan disiplin problemleri öğretmen ve öğrenci görüşleri ve il milli eğitim müdürlüğü verileri analiz edilerek ele alınmış, disiplin problemlerinin nedenlerini belirlemek amaciyla yine öğretmen ve öğrenci görüşlerine başvurulmuştur.

\section{Okullarda yaşanan disiplin problemlerine ilişkin sonuçlar}

Malatya Milli Eğitim Müdürlügünden elde edilen verilere göre okullarda en yoğun şekilde yaşanan disiplin problemleri sınıfin huzurunu bozma, kavga, sigara içme, okul malına zarar verme ve ögrencileri tehdit etme davranışlarıdır. Bu davranışlardan sinıfin huzurunu bozma, ögrencileri tehdit etme, okul araç gereçlerine zarar verme ve hırsızlık davranışları ortaokullarda daha yoğun bir şekilde görülmektedir. Duran (2011) araştırmasında, dersin akışını ve düzenini bozucu faaliyette bulunmak davranışının okul yönetimine en fazla yansıyan disiplin sorunlarının başında geldiğini ifade etmektedir. Siyez (2009) eğitim kademesinden bağımsız olarak öğretmenlerin, akademik yaşantıyı engelleyici davranışları en önemli sorunlar arasında gördüğünü belirtmektedir. Bu olayların yoğunluğu, öğrencilerin sınıfin huzurunu bozucu davranışlarının sınıf yönetimi açısından sorun teşkil ettiği şeklinde yorumlanabilir. Bu sorunun 
çözümünde öğretmenlerin sınıf yönetimine ilişkin becerilerini geliştirmek için hizmet-içi seminerler düzenlenebilir.

Kavga ve sigara içme davranışları ise liselerde daha yaygındır. Yapılan araştırmalarda liselerde meydan gelen en yaygın olayların başında okul içi ve dışındaki kavgalar geldiği sonucuna ulaşılmıştır (Duran, 2011; Durmuş ve Gürhan, 2005). Bu durum bir arada yaşamanın gereği olarak iletişimde anlaşmazlıkların çatışmalara dönüşebildiği, sorunların çözümünde öğrencilerin kavgaya başvurdukları şeklinde değerlendirilebilir. Bu tür sorunların çözümü için bu duruma neden olan etmenlerde olduğu gibi ilgili rehberlik servisi tarafindan bilgilendirme toplantıları düzenlenmeli, öğrencilere yaptıkları davranışın doğurabileceği sonuçlarla ilgili yaptırımlar hatırlatılmalı ve sorun oluşmadan engel olunmalıdır.

Araştırmada elde edilen öğretmen ve öğrenci görüşleri disiplin problemlerinin daha çok Bazen düzeyinde yoğunlaştığını göstermektedir. Öğretmenler Koridor ve merdivenlerde birbirini itme, gürültü ve kargaşa yaşanması en sık karşılaşılan problem olduğunu düşünmektedir. $\mathrm{Bu}$ durumun öğrencilerin ders aralarında daha rahat hareket etme ya da derste sürekli oturmaktan kaynaklı olarak sıkılma ve enerjilerini boşaltma isteklerinden kaynaklandığı söylenebilir. Sarpkaya (2007), disiplin problemlerinin nedenleri ile ilgili olarak sıkılma, dersten çıkmanın verdiği rahatlık, uygar yaşam tarzını bilmeme, havanın sıcak, soğuk olması gibi fiziksel koşulların öğrencilerin bu davranışları sergilemesinde etkili olduğunu ifade etmiştir. Koridor ve merdivenlerde kargaşa yaşanmaması için ders içinde öğretmenler, sınıf rehber öğretmenleri, bilgilendirme toplantıları yoluyla rehber öğretmenler ve törenlerde okul yöneticileri okul kurallarını hatırlatmalı, bu kuralların uygulanması sürecinde de paydaşlar birlikte ve tutarlı bir şekilde hareket etmelidir.

Öğretmen görüşlerine göre; öğrencilerin giyim tarzlarının kllık-klyafet kurallarına uygun olmaması, dersin akışını ve sınıf düzenini bozacak tavır ve davranışlar sergileme, dersle ilgili araç-gereçleri yanında bulundurmama ve sınıf, kantin, soyunma odası ve lavaboları temiz kullanmama davranışları da sık rastlanan disiplin problemleridir. Öğrenci görüşlerine göre ise okullarda en çok yaşanan disiplin problemleri ögrencilerin giyim tarzlarının kılık-klyafet kurallarına uygun olmaması, sinıf, kantin, soyunma odası ve lavabolar temiz kullanmama, koridor ve merdivenlerde birbirini itme, gürültü ve kargaşa yaşanması, argo ve kaba ifadeler kullanma ve ögrencilere lakap takmadır.

Öğretmen görüşleri, Öğretmenlere karşı saygısız davranışlarda bulunma ve Yöneticilere, memurlara ve diğer görevlilere hakaret etmek davranışları konusunda öğrenci görüşleriyle anlamlı şekilde farklılık göstermekte ve bu olumsuz davranışları ciddi sorunlar olarak algılamaktadır. $\mathrm{Bu}$ bulguya göre öğretmenlerin, öğrencilerin kendilerine ve okuldaki diğer görevlilere saygısız davranışlarda bulunmasını ve verilen görev ve sorumlulukları yerine getirmemelerini önemli sorunlar olarak gördükleri anlaşılmaktadır. Siyez (2009), öğretmen görüşlerine göre öğrencilerin öğretmenlerine yönelik olumsuz davranışlarda bulunduklarını ifade etmiştir. Öğretmenlere diklenme, karşılık verme ve onlara karşı saygısız davranışlarda bulunma okullarda karşılaşılan olumsuz öğrenci davranışlarıdır.

Öğrenci görüşleri kopya çekme, argo ve kaba ifadeler kullanma davranışlarıyla ilgili olarak öğretmen görüşleri ile anlamlı şekilde farkl1lık göstermekte ve ögrenciler bu olumsuz davranışları ciddi sorunlar olarak algılamaktadır.

Öğretmen görüşlerine göre koridor ve merdivenlerde birbirini itme, gürültü ve kargaşa yaşanması davranışı ortaokullarda daha çok yaşanmaktadır. Araştırmanın birinci alt probleminde sunulan Malatya Milli Eğitim Müdürlüğünden elde edilen Şiddet Olayları Formu'na ilişkin veriler bu bulguyu doğrular niteliktedir. Öğrenci görüşlerine göre Törenler sırasında saygısız davranışlarda bulunma davranışı ortaokullarda yaygın olarak karşılaşılan bir durumdur.

Öğretmen görüşlerine göre cep telefonu ve kamerayı kötü amaçlı kullanma davranışı liselerde yaygın olarak görülmektedir. Öğrenci görüşlerine göre ise lise öğrencileri ortaokul öğrencilerine göre daha fazla okuldan kaçma eğilimi göstermektedir.

Mesleki ve Teknik Liselerde araştırmada belirtilen bütün disiplin problemlerinin yaşanma sıklığının diğer lise türlerine göre daha yaygın olduğu anlaşılmaktadır. Fen Liseleriyle karşılaştırıldığında, Mesleki ve Teknik Liselerde en sık karşılaşılan problemler; okuldan kaçma, 
dersle ilgili araç-gereçleri yanında bulundurmama, kavga etme, koridor ve merdivenlerde birbirini itme, gürültü ve kargaşa yaşanması ve başkasının malın haberi olmadan almayı alışkanlık hâline getirmektir.

Okulla ilgisiz kişilerin okul içerisinde ve çevresinde öğrencileri rahatsı etmesi, öğrencilerin yanlarında kesici ve delici aletler bulundurması, okuldan kaçma, ögretmenlere karşı saygısız davranışlarda bulunma, kavga etme ve başkasının malına zarar vermek davranışları mesleki ve teknik liselerde fen liselerine oranla daha yaygındır. Fen liseleriyle kıyaslandığında, Anadolu liselerindeki öğrencilerin daha fazla kavga eğilimli olduğu anlaşılmaktadır.

Okullarda yaşanan disiplin problemlerinin nedenlerine ilişkin sonuçlar

Araştırmaya katılan öğretmenlerin okullarda yaşanan disiplin problemlerinin nedenleri ölçeğinin; Öğretmenden Yönetimden Öğrenciden ve Okul kaynaklı nedenler boyutlarında yer alan nedenleri orta düzeyde etkili, aileden ve başarısızlıktan kaynaklanan nedenleri ise çoğunlukla etkili olarak algıladıkları belirlenmiștir. Araștırmaya katılan öğrencilerin ise okullarda yaşanan disiplin problemlerinin nedenleri ölçeğinin bütün boyutlarında yer alan nedenleri orta düzeyde etkili olarak algıladıkları belirlenmiştir.

Araştırmada statü (öğretmen-öğrenci) ile yönetimden, aileden, okuldan, başarısızlıktan ve öğrenciden kaynaklanan nedenler arasında; cinsiyet ile aileden, başarısızlıktan, öğrenciden ve yönetimden kaynaklanan nedenler arasında; okul türü ile öğretmenden, aileden ve okul kaynaklı nedenler arasında anlamlı farklılıklara rastlanmıştır.

Disiplin problemlerinin nedenlerine dair öğretmen ve öğrenci görüşleri arasındaki analamlı farklılaşmalara rastlanmıştır. Öğretmenler disiplin sorunlarının nedenleriyle ilgili olarak kendileriyle ilgili nedenleri ön plana çıkarmaktadır (Öz, 2012; Sarpkaya, 2005). Öğretmenlerin sınıf yönetimi becerilerinin istenmeyen davranışların oluşmasında etkili olduğu söylenebilir. Yapılan bir araştırmada öğretmenlerin iletişime yönelik sınıf içi istenmeyen öğrenci davranışlarını yönetmede yetersiz kaldıkları ya da önemsemedikleri ifade edilmektedir. Sınıf içi istenmeyen öğrenci davranıșlarının en önemli nedeni can sıkıntısıdır (M. Başar, 2011). Bu durum sınıf içerisinde bir takım disiplin problemlerinin oluşmasına neden olabilmektedir. Disiplini sağlamada başarılı öğretmenlerin dersi işlemede daha başarılı, sorunlarının çözümünde ise daha 1lımlı olduğunu (Aydın, 2001) Öğretmenin sınıf içerisindeki iletişimi, kullandığg disiplin teknikleri disiplin sorunlarının oluşmasında etki eden önemli bir etmendir. Öğretmenin olumlu, güvene dayalı ilişkiler kurmasının sınıftaki aksaklıkların sayısını azalttığı ve ilişkisel disiplinin sınıftaki aksaklıklar azaldığında öğrenmeyi kolaylaştıran bir okul ortamının gelişmesini sağladığı söylenebilir. Bu durum hem öğretmen hem de öğrenciler için fayda sağlayacak olumlu bir sosyal değişim sağlayabilir (Nouffer, 2011).

Öğretmenler öğrencilerle karşılaştırıldığında disiplin sorunlarının daha çok aile ve öğrenci başarısızlığından kaynaklandığını, öğrenciden kaynaklı olduğunu düşünmektedir. Araştırma bulguları, bu bulguyu destekler niteliktedir. Öyle ki, yapılan araştırmalarda, öğretmen görüşlerine göre disiplin sorunlarının en önemli nedeninin aileden kaynaklanan olumsuzluklar olduğu anlaşılmaktadır (Çetin, 2002; Öz ve Sadık, 2015; Tucker, 1998). Aile ilgili birçok faktör bu duruma neden olabilmektedir. Güçlü (2004) araştırmasında, kardeş sayısının, ailenin ekonomik durumunun, anne babanın tahsil durumunun, hali hazırda ikamet edilen ve çocukluğun geçirildiği yerin, anne ve babanın mesleğinin öğrencilerin disiplin suçu işlemesinde etkili olduğunu ifade etmektedir. Kardeş sayısı fazla olan öğrencilerin daha çok suç işleme eğiliminde oldukları, ailenin ekonomik durumu iyileştikçe suç işleme oranlarının azaldığı, ekonomik duruma göre işlenen suç türlerinin farklı olduğu, anne babanın öğrenim durumu yükseldikçe çocuğun suç işleme oranlarının azaldığı görülmüştür. Bununla birlikte, Güzel (2014), disiplini bozan öğrenci davranışlarının en önemli nedenlerinden birinin ailelerin çocuklarının eğitimine olan ilgisizliği olduğunu ve Aydın (2001), Bal (2005) ve Demir (2013) öğretmenlerin sınıf içinde karşılaştıkları disiplinsiz davranışların nedeninin, ailelerin çocuklarının eğitimine olan ilgisizliği olduğunu, Hill (1993) ailenin daha fazla katılımının disiplin sorunlarının azalmasını sağlayabileceğini ifade etmişlerdir. 
Öğrenci başarısıyla disiplin sorunlarının meydana gelmesi arasında anlamlı ilişki olduğu saptanmıştır. Yapılan araştırmalar bu bulguyu doğrular niteliktedir. Disiplin sorunlarının meydan gelmesinde öğrencilerin akademik başarılarının etkili olduğu (Aydın, 2001; Ereskici 2006; Güçlü, 2004; Warren, 2007) anlaşılmaktadır. Kuş ve Karatekin, (2009) derslerinde kendini gösteremeyen öğrencilerin kendini daha farklı şekilde göstermek istediği ve ögrencilerin akademik başarıları düştükçe okul kurallarını ihlal etmelerinin de arttı̆̆ sonucuna ulaşmıştır. Öğretmen görüşlerine göre, okulda başarı durumu zayıf olan öğrenciler daha çok suç işleme eğilimindedir (Güçlü, 2004). İnce (2011), akademik başarı yükseldikçe, sınıf disiplini ile ilgili öğrencilerin, çağdaş disiplin uygulamalarını benimseme oranlarının yükseldiğini, Aktaş (2009) ise sınıf tekrarı yapan öğrencilerin daha fazla disiplin işlemlerine tabi tutulduğunu ifade etmektedir. Crowder'a (2008) göre, öğrenciler akademik olarak başarılı olduklarında beladan kaçmak için olumlu davranışlar sergilemektedir.

Araştırmaya katılan öğretmen ve öğrencilerin okulla ilgili özelliklerin ve süreçlerin disiplin problemlerine orta düzeyde neden olduğunu düşünmektedir Öğrenci görüşleri okul kaynaklı nedenlerin disiplin problemlerinin oluşmasında etkili olduğu konusunda öğretmen görüşleri ile anlamlı bir şekilde farklılaşmaktadır. Okul iklimi ile öğrenci başarımı arasında ilişki olduğu, okuldaki olumsuz etkenlerin varlığının öğrencinin başarımını etkilediği bunun da disiplin problemlerine neden oluşturduğu saptanmıştır (Warren, 2007).

Öğrenciler okul idaresinin yönetim sürecine ilişkin tavır ve davranışlarının disiplin problemlerinin meydana gelmesinde etkisi olduğunu düşündükleri söylenebilir. Yapılan bir araştırmada okul yöneticilerinin olaylara yaklaşımını ve yeterliliğinin okulda yaşanan disiplin problemlerinin meydana gelmesinde etkili olduğunu göstermektedir (Aygün, 2013).

Kadın öğretmenler disiplin sorunlarının daha çok aileden kaynaklı olduğunu düşünmektedir. Yapılan araştırmalar bu bulguyu doğrular niteliktedir. Demir (2013) öğretmen görüşlerine göre ailelerin çocuklarının eğitimine olan ilgisizliğinin ve ailelerin çocuklarına karşı olumsuz tutum ve davranışlarının öğretmenlerin sınıf içinde karşılaştıkları disiplinsiz davranışların nedeni olduğu konusunda cinsiyete göre anlamlı bir farklılık olduğu sonucuna ulaşmıştır. Baysal (2009), bayan öğretmenlerin erkek öğretmenlere oranla aileyi disiplin sorunlarının kaynağı olarak daha fazla görmekte olduğu sonucuna ulaşmıştır. Aile ile ilgili durumlar bayan öğretmenlere göre disiplin sorunlarına daha fazla yol açmaktadır.

Araştırmada elde edilen verilere göre okulda yaşanan disiplin problemlerinin nedeni olarak öğrenci kaynaklı nedenlerin etkileri olduğu söylenebilir. Yapılan araştırmalarda öğrencinin cinsiyet, sınıf seviyesi ve yaş (Çelik, 2007) gibi bireysel özellikleri, sosyal ilişkileri, öğrencilerin eğitime, okula, toplumsal çevreye ilişkin algıları ve buna bağlı duygusal durumlarının davranışlarına yön vermesi (Tunç ve diğerleri, 2015) ile disipline aykırı davranışta bulunma durumlarının birbirine bağımlı olduğu görülmektedir.

Lise öğrencileri ortaokul öğrencileri ile karşılaştırıldığında disiplin sorunlarının öğretmenden aile, okul kaynaklı olduğunu düşünmektedir. Yapılan araştırmalarda öğrencinin yetiştiği çevre, arkadaş ortamı (Gökyer ve Doğan, 2016), cinsiyet, sınıf seviyesi ve yaş (Çelik, 2007) gibi özellikleri disiplin problemlerinin oluşmasına kaynaklık etmektedir. Sınıf seviyesi yükseldikçe okul kurallarını ihlal etmede artış olduğu, okul kurallarına aykırı davranışlarda bulunma oranının arttığı görülmektedir. Şenses (1990) öğrencilerin yaşları büyüdükçe disipline aykırı davranışlarda artış olduğunu; disipline aykırı davranışların cinsiyete göre dağılımında erkek ögrencilerin kız öğrencilerden daha fazla disipline aykırı davranışta bulunduklarını ifade etmektedir. Öğrencilerin okul kurallarını ihlal etmesinin nedeni, bu ihlallerin ağır cezalar gerektirmemesi, sıradan davranışlar olarak görülmesi ve idareci, öğretmenler tarafından hoş görülmesi olarak ifade edilmektedir (Kuş ve Karatekin, 2009). Yapılan araştırmalarda ergenlik çağının etkisi (Bilir ve Tezcan, 2007), öğrencilerin gelişim özellikleri ve gelecek kaygılarının olmaması da okulda disiplini bozan davranışların nedenleri olarak gösterilmektedir (Tunç ve Doğan, 2015). 


\section{Kaynaklar}

Ada, S. ve Çetin, M. Ö. (2006). Ĕ̈itim ve ögretim ortamında disiplin nedir? İstanbul: Nobel Yayınlar1.

Aktaş, K. (2009). Disiplin soruşturması açılan öğrencilerin aile profilleri: İstanbul ili Bayrampaşa ilçesi İnönü Anadolu Teknik, Teknik ve Endüstri Meslek Lisesi örneği. (Yayımlanmamış yüksek lisans tezi). Beykent Üniversitesi, Sosyal Bilimler Enstitüsü, İstanbul.

Altunışık, R., Coşkun, R., Bayraktaroğlu, S.ve Yıldırım, E. (2010). Sosyal bilimlerde araştırma yöntemleri; SPSS uygulamalı (6. Baskı) Sakarya: Sakarya Yayıncılık.

Aydın, B. (2001). İlköğretim okullarında sınıf disiplininin sağlanması. Yayımlanmamış Doktora Tezi. (Yayımlanmamış doktora tezi) Abant İzzet Baysal Üniversitesi, Sosyal Bilimler Enstitüsü. Bolu.

Aygün, A. (2013). Anadolu liselerinde görev yapan öğretmenlerin karşılaştıkları disiplin problemleri ve bunlara baș etme yolları (Yayımlanmamıș yüksek lisans tezi). Yeditepe Üniversitesi, Sosyal Bilimler Enstitüsü. İstanbul.

Bal, T. (2005). İlköğretim 3. ve 5. sinıf ögretmenlerinin disiplin anlayışları ve kullandıkları disiplin yöntemleri (Konya ili Örneği). (Yayımlanmamış yüksek lisans tezi). Selçuk Üniversitesi Sosyal Bilimler Enstitüsü. Konya.

Başar, H. (1999). Sinıf yönetimi. İstanbul: MEB Yayınları, Öğretmen Kitapları Dizisi.

Başar, M. (2011). Sinıf içi istenmeyen ögrenci davranışlarının yönetiminde örtük program: Uşak ili örneği. (Yayımlanmamış doktora tezi). Marmara Üniversitesi, Eğitim Bilimleri Enstitüsü. İstanbul.

Başaran, İ. E. (1994). Ĕgitime giris, Ankara, Kadığlu Matbaası, 1994.

Başaran, İ. E. (2000).Eğitim yönetimi nitelikli okul. Ankara: Feryal Matbaası.

Baysal, N. (2009). İlköğretim II. kademede görevli öğretmenlerin sinıfta karşılaştıkları disiplin sorunlarına, bunların nedenlerine ve çözüm yollarına ilişkin görüşleri (Diyarbakır ili örneği). Yayımlanmamıș Yüksek Lisans Tezi, (Yayımlanmamış yüksek lisans tezi). Dicle Üniversitesi Sosyal Bilimler Enstitüsü, Diyarbakır.

Bilir, A., Kuru, S. ve Tezcan, F. (2007). Muğla ili ortaöğretim okullarında disiplin uygulamalarına ilişkin yönetici ve öğretmen görüşleri. Muğla Üniversitesi Sosyal Bilimler Enstitüsü Dergisi. (19). Erişim adresi: http://www.istanbuluniversitesi.dergipark.gov.tr/musbed/is sue/23520/250604

Büyüköztürk, Ş. (2014). Sosyal bilimler için veri analizi el kitabı. Ankara: Pegem Akademi.20. Bask1.

Cangelosi, J. S. (2016). Sinıf Yönetimi Stratejileri: Öğrencilerin İşbirliği yapmalarını sağlama ve bu işbirliğini devam ettirme. (R. Hoş ve M. Toprak, Çev.) (7 basımdan çeviri). Ankara: Nobel Akademik Yayıncılık.

Celep, C. (2000). Sinıf yönetimi ve disiplini. Ankara: Anı Yayıncılık.

Çelik, B. (2007). İstanbul ili Anadolu yakası orta dereceli okul ögrencilerinin disipline aykırı davranışlarda bulunma nedenlerinin araștırılması (Yayımlanmamıs yükssek lisans tezi). Yeditepe Üniversitesi, Sosyal Bilimler Enstitüsü, İstanbul.

Çetin Y. (2002). Illköğretim 4 ve 5. sinuf öğretmenlerinin sinufta karşılaştıkları disiplin problemleri ile ilgili görüşleri. Yayınlanmamış Yüksek Lisans Tezi. (Yayımlanmamış yüksek lisans tezi). Çukurova Üniversitesi / Sosyal Bilimler Enstitüsü. Adana.

Crowder, G. R. (2008). Why students misbehave: An investigation into the reasons given by elementary school-aged students. (Yayımlanmamış doktora tezi). Fielding Graduate University. Erişim adresi: http://search.proquest.com/docview/304838483? accountid $=16268$.

Demir, F. (2013). Ortaokullarda öğrencilerin disiplinsiz davranışları ve bu davranışların sebepleri (Batman ili merkez ilçesi örneği). (Yayımlanmamış yüksek lisans tezi). İnönü Üniversitesi / Eğitim Bilimleri Enstitüsü.

Deshmukh, A. V. ve Naik, Anju P. (2010). Educational Management. Mumbai: IND: Himalaya Publishing House. 
Duran, O. C. (2011), Ortä̈ğretim kurumlarında okul yönetimine yansıyan disiplin sorunları okul yöneticilerinin çözüm yaklaşımları: Uşak ili örneği (Yayımlanmamış yüksek lisans tezi). Uşak Üniversitesi, Sosyal Bilimler Enstitüsü. Uşak.

Durmuş E. ve Gürhan, U. (2005). Lise öğrencilerinin şiddet ve saldırganlık eğilimleri. Gazi Üniversitesi Türk Ë̆itim Bilimleri Dergisi, 3.

Edwards, C. H. (2004). Classroom discipline and management. USA 4th Edition, Wiley and Sons Inc.

Ereskici, E. (2006). Meslek liselerinde öğrencilerinin disipline aykırı davranışlarda bulunma nedenleri (Ankara ili örneği). (Yayımlanmamış yüksek lisans tezi). Gazi Üniversitesi, Eğitim Bilimleri Enstitüsü. Ankara.

Field, A. (2005). Discovering statistics using SPSS. (2.Bask1). London: Sage Publications.

Fraenkel, J. R., Wallen, N. E. ve Hyun, H. H. (2012). How to design and evaluate research in education (8. Bask1). New York: McGraw-Hill.

Gökyer, N. ve Doğan, B. (2016). İstenmeyen öğrenci davranışları ve nedenlerine ilişkin yönetici ve öğretmen görüşleri. Firat Üniversitesi Sosyal Bilimler Dergisi, 26(1), 93-105.

Güçlü, M., (2004). Ortä̈ğretim kurumlarında disiplin cezası alan öğrencilerin sosyoekonomik yönden incelenmesi (Kayseri örneği). (Yayımlanmamış yüksek lisans tezi). Erciyes Üniversitesi, Sosyal Bilimler Enstitüsü. Kayseri.

Gupta, K. (2006). School Management. Delhi, IND: Pragun Publications.

Gürbüz, S. ve Şahin, F. (2014). Sosyal bilimlerde araştırma yöntemleri. Ankara: Seçkin Yayıncilik.

Güven, M. B. Dönmez, (2002). Ortaöğretim öğrencilerinin okul güvenliğine ilişkin algi ve beklentileri. İnönü Üniversitesi Eğitim Fakültesi Dergisi, 3(4), 59-68.

Güvenç, B., Otkan, P., Belek, T., Akarsu, F., Tözeren, S. ve Özden, M. A. (1990). Japon egitimi. İstanbul: Milli Egitim Bakanlıg1 Yayınları: 1185

Güzel, H. (2014). Din kültürü ve ahlak bilgisi öğretmenlerinin disiplini bozan öğrenci davranışlarına karşı tutumları. (Yayımlanmamış yüksek lisans tezi). Marmara Üniversitesi, Sosyal Bilimler Enstitüsü, İstanbul.

İnce, B. (2011). Sinıfta istenmeyen davranışlara karşı ögretmenlerin disiplin uygulamalarıyla ilgili ilköğretim 5. sinlf öğrencilerinin görüşlerinin incelenmesi (Istanbul ili örneği) (Yayımlanmamış yüksek lisans tezi). Marmara Üniversitesi, Eğitim Bilimleri Enstitüsü. İstanbul.

Kahveci, N. G. (2012). Genel liselerde karsilasilan disiplin sorunlarinin uzamsal incelenmesi: İstanbul'dan bir ilçe örnegi. Educational Policy Analysis and Strategic Research, 7(1), Erişim adresi: http://dergipark.gov.tr/download/article-file/161884

Kline, R. B. (2010). Principles and practice of structural equation modeling. (3. Bask1). New York: Guilford Press.

Kuş, Z. ve Karatekin, K. (2009). Öğrencilerin okul ortamında kurallara uygun davranma yeterliklerinin çeşitli değişkenler açısından incelenmesi. Ahi Evran Üniversitesi Kırşehir Eğitim Fakültesi Dergisi (KEFAD), 10(1), 183-196.

Marzano, R. J. (2003). Classroom management that works: research-based strategies for every teacher. Alexandria, VA, USA: Association for Supervision \& Curriculum Development (ASCD). ProQuest ebrary.

Marzano, R. J., Marzano, J. S. ve Pickering, D. J. (2008). Etkili sinıf yönetimi stratejileri. (Çev. S. Sakac1). İstanbul: Redhouse Eğitim Kitapları.

Munn, P., Lloyd, G. ve Cullen, M. A. (2000). Alternatives to exclusion from school. London, GBR: SAGE Publications Ltd.

Nouffer, M. D. (2011). A case study on positive and relational discipline techniques. (Yayımlanmamış doktora tezi). Walden University. USA.

OECD (2011). Has discipline in school deteriorated? PISA in Focus, No. 4, OECD Publishing, Paris. DOI: http://dx.doi.org/10.1787/5k9h362q5ng4-en 
Öz, E. Z. ve Sadık, F. (2015). Ortaokul öğretmenleri ve öğrencilerinin disiplin problemleri ve başetme stratejilerine yönelik görüş ve beklentileri. Akademik Sosyal Araştırmalar Dergisi, 3(18), 151-189.

Öz, E. Z. (2012). Öğretmen, öğrenci ve ailelerin ilköğretim II. kademede gözlenen disiplin problemleri ve baş etmede kullanilan stratejiler ile ilgili görüşlerinin incelenmesi (Yayımlanmamış yüksek lisans tezi). Çukurova Üniversitesi, Sosyal Bilimler Enstitüsü. Adana.

Özdemir, A. (2007). Öğrenci disiplin işleri ve uygulamalari. E. Karip (Yay. haz.), Sinıf Yönetimi, Ankara, Pegem-A Yayınc1lık.

Sarıtaş, M. (2003). Sınıf yönetimi ve disiplinle ilgili kurallar geliştirme. L. Küçükahmet (Yay. haz.), Sinıf Yönetiminde Yeni Yaklaşımlar. Ankara,Nobel Yayınc1lı, 2003.

Sarpkaya, P. (2005). Resmi liselerde disiplin sorunlart ve ilgili grupların (öğretmen,

ögrenci, yönetici, veli) yaklaşımları. (Yayımlanmamış doktora tezi). Dokuz Eylül Üniversitesi Eğitim Bilimleri Enstitüsü, İzmir.

Sarpkaya, P. (2007). Yönetici, öğretmen, öğrenci ve velilere göre resmi liselerdeki öğrenci disiplin sorunlarinin nedenleri. Pamukkale Üniversitesi Ĕ̈itim Fakültesi Dergisi, 2(22), 110-121.

Şenses, V. (1990). Tokat ili merkez ve ilçe orta dereceli okul ögrencilerinin disipline aykırı davranışlarda bulunma nedenlerinin araştırılması, (Yayımlanmamış yüksek lisans tezi). Gazi Üniversitesi, Sosyal Bilimler Enstitüsü. Ankara.

Şimşek, H. (1997). 21. yüzyilin eşiğinde paradigmalar savaşi: kaostaki Türkiye. İstanbul: Sistem Yayıncilik.

Şişman, M. ve Turan, S. (2008). Sınıf yönetimi (6. Baskı). Ankara: Öğreti, Pegem akademi.

Siyez, D. M. (2009). Liselerde görev yapan öğretmenlerin istenmeyen öğrenci davranişlarina yönelik algilari ve tepkileri. Pamukkale Üniversitesi Ĕ̈itim Fakültesi Dergisi, 1(25), 6780.

Tosun, Ü. (2002). Onurlu disiplin. Beyaz Yayınları, İstanbul.

Tucker, G. M. (1998). Discipline: Bermuda high school student, teacher, parent, and administrator perceptions of the causes of misbehavior. (Yayımlanmamıs doktora tezi). Columbia University teachers College. USA. Erişim adresi: http://search.proquest.com/docview/30446 3208?accountid=16268?accountid=16268

Tunç, B., Yıldız, S. ve Doğan, A. (2015). Meslek liselerinde disiplin sorunları, nedenleri ve çözümü:Bir durum analizi. Abant İzzet Baysal Üniversitesi Ĕ̈itim Fakültesi Dergisi, 15(2), 384-403.

Turan, İ., Şimşek, Ü. ve Aslan, H. (2015). Eğitim araştırmalarında likert ölçeği ve likert-tipi soruların kullanımı ve analizi. Sakarya Üniversitesi Eğitim Fakültesi Dergisi, 30, 186203.

Türnüklü, A. (2006). Sınıf ve okul disiplinine çağdaş bir yaklaşım: onarıcı disiplin. Ankara: Ekinoks Yayınları.

Warren, A. F. (2007). The relationship between reported incidents of student discipline and student achievement across four eastern states. (Yayımlanmamış doktora tezi). Virginia Polytechnic and State University. USA. Erişim adresi: http://search.proquest.com /docview /304809030?accountid=16268

\section{Extended Abstract}

\section{Introduction}

The main purpose of any nation's educational system is to raise individuals with proper behaviours. Discipline problems encountered at schools have been a crucial problem day by day. The feature, type and the reasons of distruptive behaviours experienced at schools varies among schools. In order to create an effectieve teaching-learning environment, it requires much more 
time at schools where discipline problems are seen more often. According to PISA results in 2009, there is a high level of relationship between the student performance and school climate.

The aim of this study is to reveal the discipline problems at lower secondary schools and high schools and the teachers' and students' views regarding the reasons of these problems.

\section{Method}

For the study, descriptive method was used. Causal comparative research design was employed in this study in order to find out if there were significant differences in the views of teachers and students regarding discipline problems and the reasons behind these in terms of gender, teaching experience, school type and socio-economical level of the school regions variables.

In the study, the official data which were collected from schools for discipline problems in Malatya for 2015-2016 Academic Year and the teachers' and students' views on this issue were presented and the practices of discipline by school administrators to maintain discipline were analyzed by revealing the disciplinary sanctions and practices against these problems in these schools.

The population of the study includes 6.141 teachers and 68.921 students at lower secondary schools and high schools in Yeşilyurt and Battalgazi, central towns of Malatya in 20162017 Academic Year. In the study stratified random sampling method was used and the sample of the study consists of 691 teachers and 1001 students. In the study, the data from Malatya Provincial Directorate of Education related to disciplinary cases were analyzed; in 2016-2017 Academic year, the data were collected through Discipline Problems at Schools Survey and The Reasons of Discipline Problems at Schools Scale. The quantitative data was analyzed by using descriptive statistical analyses, Mann Whitney $U$ and Kruskall Wallis Tests, independent samples t-test, one-way ANOVA, and the eta- square $\left(\eta^{2}\right)$ and Cohen's d coefficient were calculated. The qualitative data was analyzed by using descriptive and content analyses.

\section{Results and Discussion}

In this study, it was aimed to determine the discipline problems and the reasons of these problems according to the data obtained from the provincial educational directorate of Malatya and the surveys.

In the light of the findings, it was found out that disruptive behaviors in class, fighting, smoking, giving harm to school properties and threatening students are the most common discipline problems at schools. Disruptive behaviors in class, threatening students, giving harm to school properties and theft are more common at lower secondary schools while fighting and smoking are more common at high schools.

According to the views of the teachers', the most common discipline problems at schools are; causing disorders in the corridors and at the stairs, displaying disruptive behaviors during the lesson, not bringing the course materials to class, not keeping the class, canteen etc. clean, not obeying the uniform rules. Students believe that the most common discipline problems at schools are; not keeping the class, canteen etc. clean, causing disorders in the corridors and at the stairs, fighting, using slang words and not obeying the uniform rules, and nicknaming. Compared to the other schools, it was found out that all discipline problems mentioned in the study have the most frequency of occurrence in Vocational and Technical High Schools.

It was found that the teachers' views are believed to be mostly effective on the items in the family and failure originated reasons subscales, and to be moderately effective for the other subscales and in total. Student views regarding the reasons of discipline problems are understood to be moderately effective for all subscales and in total while the views of teachers and students regarding the reasons of discipline problems differ significantly in all subscales and for all subscales teachers have higher means.

According to the gender variable, the views of male and female teachers differ significantly in the subscales of family, failure and student originated reasons and there is no statistically significant difference for other subscales. According to the professioanl seniority variable, there is no statistically significant difference for all subscales. 
Demirtaş ve Pehlivan

According to the gender variable, the views of male and female students differ significantly only in the subscale of administrative originated reasons and in total and there is no statistically significant difference for other subscales. According to the level of education variable, the views of students differ significantly in the subscale of teacher, family and school originated reasons and in total and there is no statistically significant difference for other subscales. 